\title{
IRON AGE TO EARLY MODERN ACTIVITY AND PALAEOCHANNELS AT MAGOR PILL, GWENT: AN EXERCISE IN LOWLAND COASTAL-ZONE GEOARCHAEOLOGY
}

\author{
By J.R.L. Allen, F.S.A. and S.J. Rippon
}

\begin{abstract}
Archaeological attention is increasingly being directed toward the challenges, and neglected but threatened resources, afforded by the lowland coastal zone. ${ }^{\mathrm{I}}$ This is exemplified by the Lindsey Coastal Survey, ${ }^{2}$ Humberside, ${ }^{3}$ the Fenland Survey, ${ }^{4}$ the Hullbridge Survey Project, ${ }^{5}$ Romney Marsh ${ }^{6}$, and the Severn Estuary Levels. ${ }^{7}$ In this zone, human activities are framed by young landscapes of great geological dynamism, which proffer substantial natural risks as well as economic opportunities. Tidal salt marshes and high mudflats, for example, can be permanently settled only after they have been wrested from the sea by building seabanks, major drains and outfall works. This is the crucial, primary process of land-claim, widely but misleadingly styled 'reclamation', a term we reject as inaccurate and misleading. It is only now, however, that outfall works and seabanks are being recognized as defining landscape monuments, of the highest significance. Where relative sea level is rising, erosion threatens sea defences, which may have to be set back (i.e. repositioned further inland), with the possible loss of agriculturally improved land, settlements, and port facilities. Architectural materials and occupation debris may consequently become thickly buried under new sediments, transferred in various ways and at more than one time into deep channels, or even transposed as pebbles into the modern intertidal zone. Under these circumstances, sound interpretations result only by following an eclectic, trans-zonal approach that integrates documentary and conventional archaeological evidence with a full appreciation of geological and geomorphological processes and their consequences and expression.

In illustration of these points, we describe in this paper the important, multiperiod site at Magor Pill on the alluvial coast of south-east Wales. Here, on the shores of the extensive, agriculturally improved land-claim known as the Gwent Levels, significantly reduced by coastal erosion, a complex of silted-up tidal channels preserves most of what survives from trading, tidewater occupations of the Iron Age onwards. Archaeologically, Magor Pill presents great depth in time, but its geological development has ensured that the successive landscapes that framed the activities have been largely lost. Inevitably, and in contrast to much coastal archaeological work, we have given as close attention in reaching our conclusions to the immediate hinterland of Magor Pill as to the intertidal zone. Essentially, we approached the problem holistically, seeking to match the documentary and conventional archaeological evidence at the site to a detailed geological and geomorphic framework which we established.

The palaeochannels are exposed on a large intertidal outcrop of Flandrian estuarine deposits, the cover of mobile, contemporary sediment generally being least during the winter. We surveyed the foreshore and pegged out the chief geological boundaries before
\end{abstract}


planning them with an electronic distance measurer. Outcrops were intensively linewalked on a number of occasions in order to survey and recover artefacts, structural features, and embedded driftwood from the palaeochannel and other sediments. Driftwood was accepted for radiocarbon dating only if unabraded and bark-covered, and so unlikely to be residual. Transposed artefacts are chiefly associated with gravel sheets and patches; these deposits also were intensively line-walked several times, in order to secure reliable collections. Medieval and later pottery was identified partly by reference to material described from Bath, ${ }^{8}$ Gloucester, ${ }^{9}$ Bristol ${ }^{10}$ and, especially, Chepstow. ${ }^{\text {II }}$ Tidal silts from the palaeochannels were sampled for grain-size analysis, in order to help correlate disconnected exposures, relate the site to the contemporaneous shoreline, and identify possible chronological changes of hydraulic regime. ${ }^{\mathrm{I}}$ We emphasize that the intertidal zone at Magor Pill is not to be dissociated from the landscape in the immediate hinterland, defended by a sea wall. In particular, we sought evidence in that landscape of redundant sea defences and tidal outfalls. Documentary evidence on settlement, trading activities, and flood defences was especially helpful in elucidating the complex sequence of archaeological events at Magor Pill.

\section{GENERAL SETTING}

Magor Pill is a tidal stream emptying into the Severn Estuary toward the north-eastern end of the Caldicot Level, one of the larger of the outcrops of Flandrian estuarine alluvium that make up the Severn Estuary Levels (fig. Ia, b). These total c. $84 \mathrm{okm}^{2}$ in area and conceal about $8 \mathrm{~km}^{3}$ of freshwater to shallow-marine silts, sands and peats, ${ }^{13}$ which together make up the Wentlooge Formation. ${ }^{14}$ The beds, similar in sequence throughout the area (fig. Ic), rest on an uneven, dissected surface of bedrock, beach or fluvial gravel, and head deposits affected in various ways by pre-Flandrian periglacial processes. ${ }^{15}$ Typically, at the base is a soil grading locally to a thin peat. Above come the thick, mainly estuarine silts and some sands which make up the informally named lower Wentlooge Formation. Broadly at about Ordnance Datum are a few metres of intercalated brackish-freshwater peats and estuarine silts, the middle Wentlooge Formation (6500-2500 years BP). These peats tend to thicken and include increasingly supratidal facies toward the landward margins of the Levels and toward bedrock 'islands' such as Goldcliff. Thick estuarine silts return in the upper Wentlooge Formation. Beginning in Roman times, ${ }^{16}$ land-claim has halted tidal deposition on all naturally occurring marshes of the Levels, excepting marshes in a small, surviving fringe along the coast. Prolonged agricultural improvement has subsequently destroyed almost all surface evidence of the branching tidal channels that may be presumed to have reached back deep into the marshes from the coast. ${ }^{17}$ In the cultivated Fenland, by contrast, surface traces of the creek networks abound. ${ }^{18}$

The pill originates as the St Bride's Brook (fig. Id), rising in and flowing through low hills of Old Red Sandstone, Carboniferous and Triassic rocks to the north of Magor village. ${ }^{19}$ South of Magor, a partly raised and artificial cut, Mill Reen, carries water across the estuarine alluvium to the shore (figs Id, 2a). An important and almost parallel tributary, called Pratt Reen, joins Mill Reen on the left bank. Today's outfall is a sluice in the seabank at the open coast, but the tide formerly reached to points much further inland (see below). Beyond the seabank, the modern tidal channel meanders through salt 

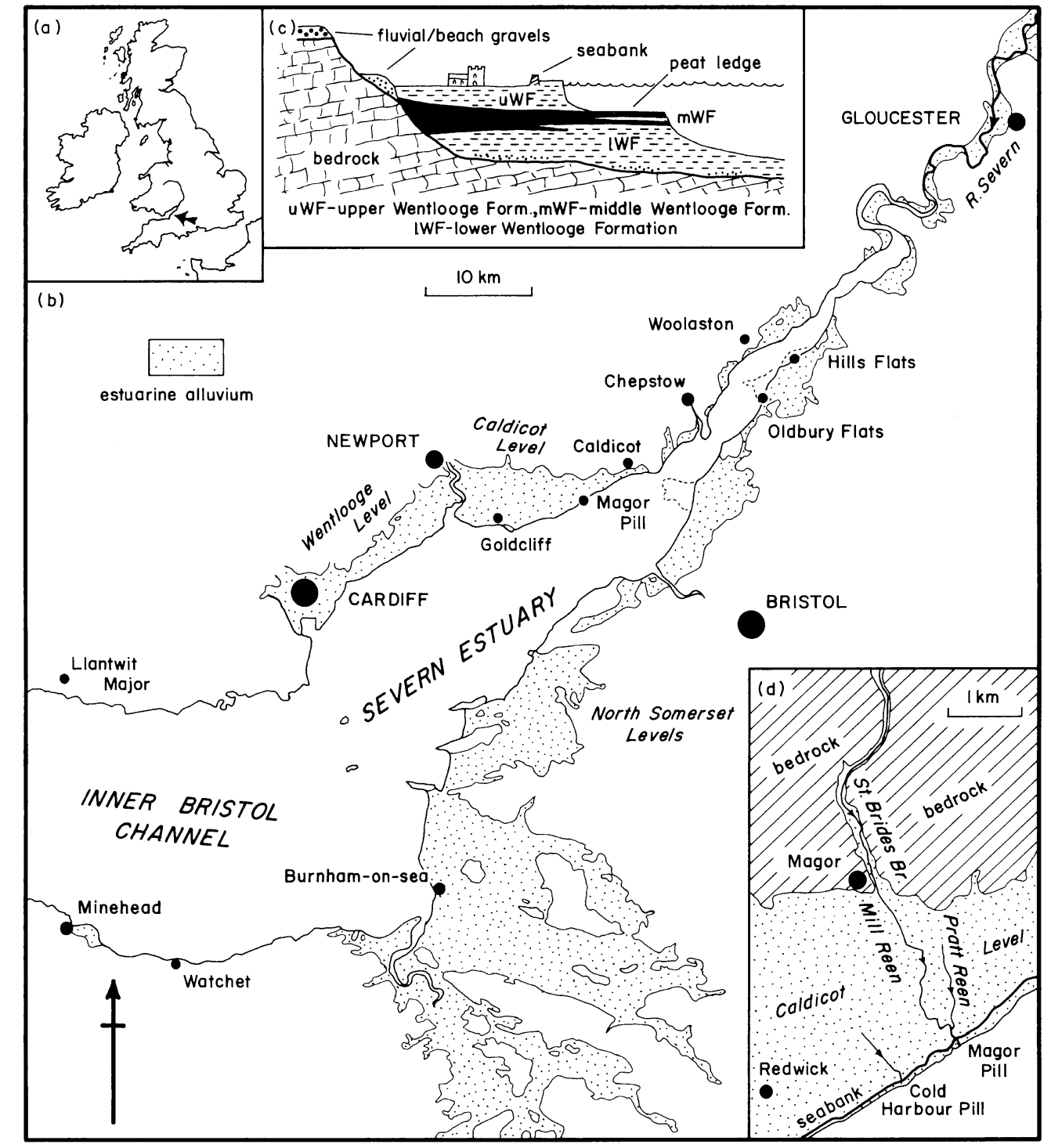

$10 \mathrm{~km}$

Fig. I. Magor Pill and the Severn Estuary Levels (a) location, (b) The Severn Estuary Levels, (c) standard stratigraphy of the Wentlooge Formation (Flandrian), (d) Magor Pill in the Caldicot Level

marshes and across the raised upper foreshore, only to peter out on the wide, lower foreshore in shallow, branching washes.

Figure 3 gives a section across the seabank, marshes, and foreshore area (fig. 2a, b). The section commences, on the right hand side, with the record of a borehole (N. G. Ref. ST 435850 ) at the Sewage Treatment Works. ${ }^{20}$ Drilling proved $c .8 .8 \mathrm{~m}$ of the Wentlooge Formation below a land surface at $c .6 .7 \mathrm{~m}$ OD which cannot have been embanked later 


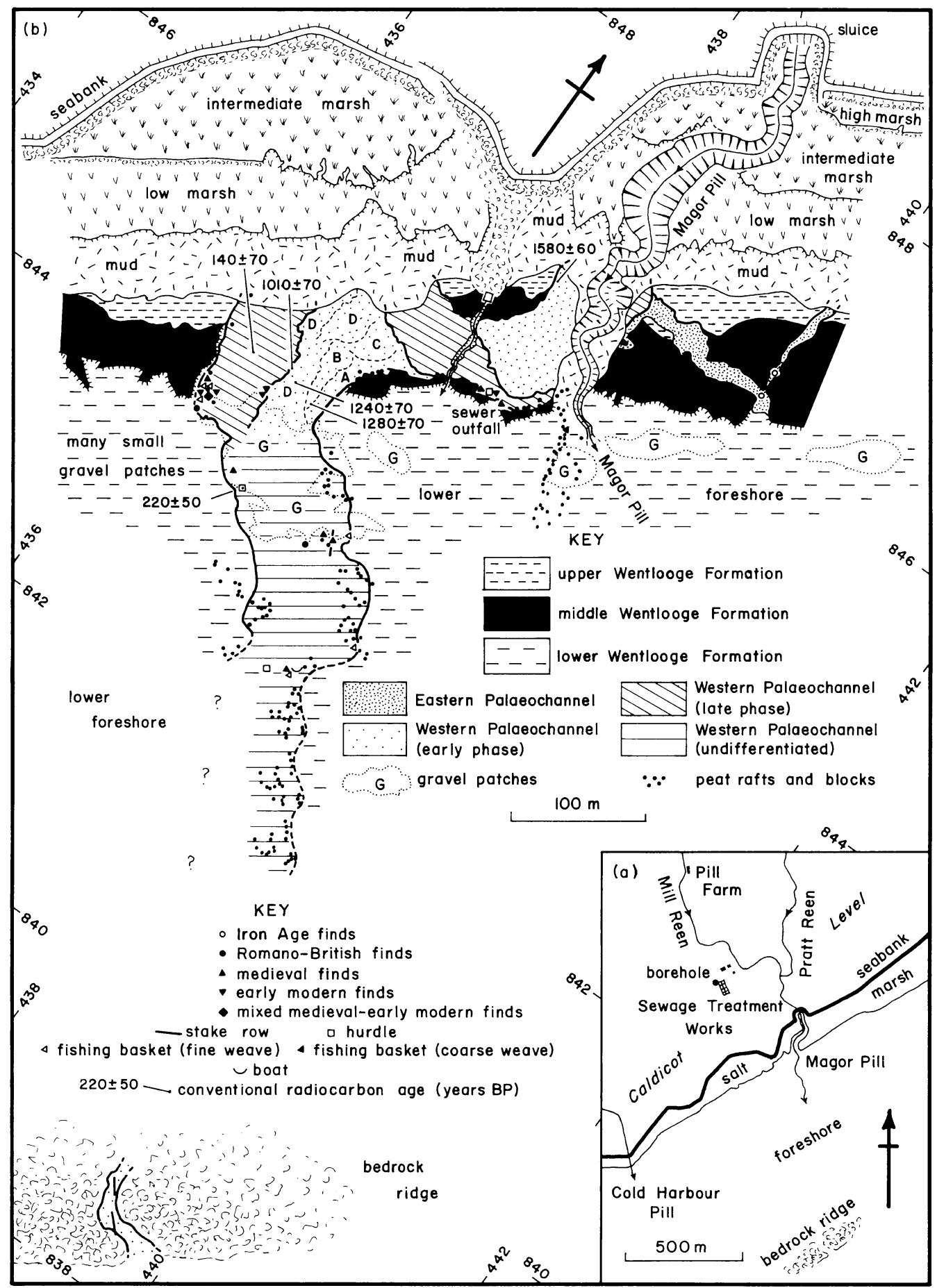

Fig. 2. Magor Pill (a) general features of the area, (b) geoarchaeological map showing the palaeochannels and their context 


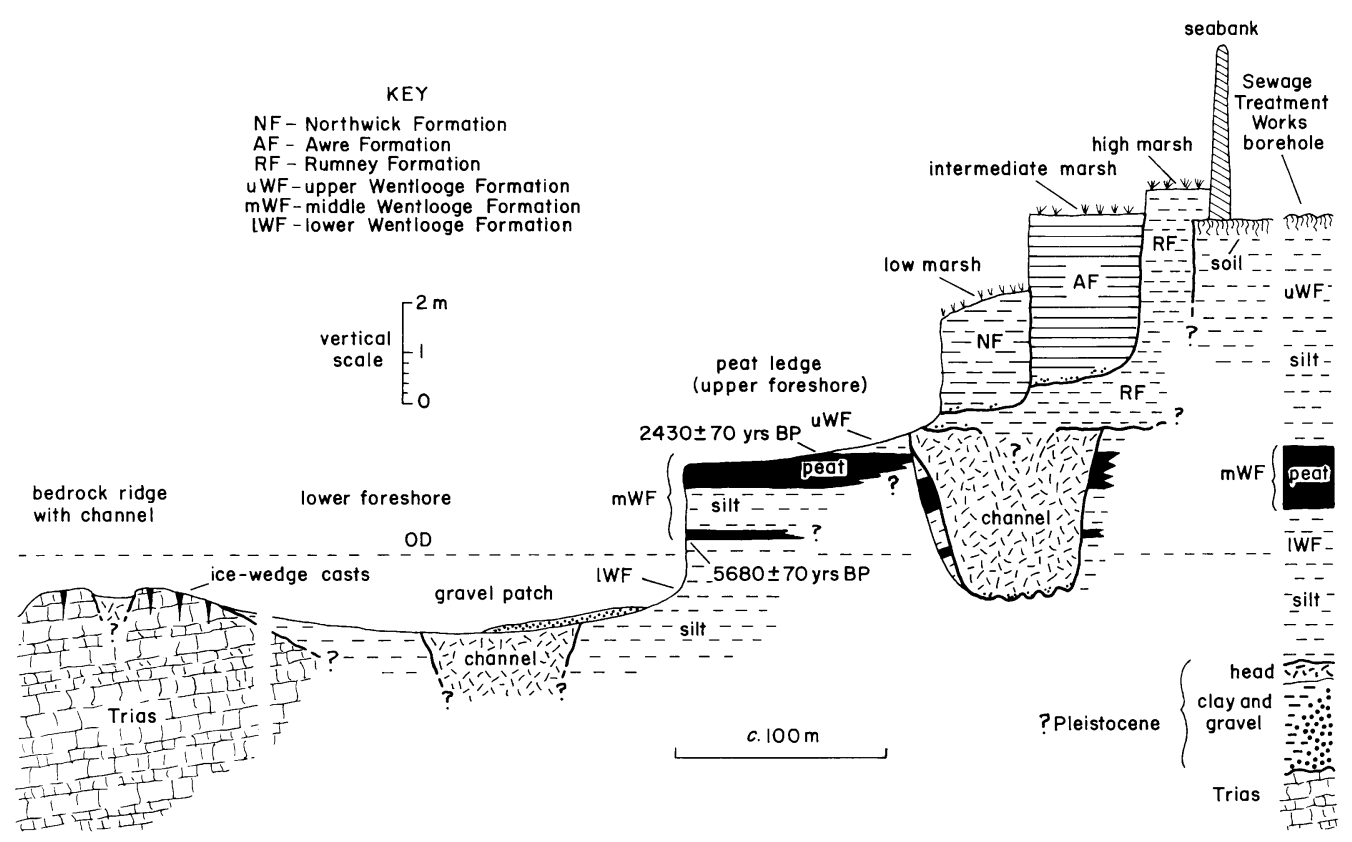

Fig. 3. Partly generalized stratigraphic section at Magor Pill from the Sewage Treatment Works to the bedrock ridge

than the early twelfth century (see below). Sandwiched between thick silts was a peat $\mathrm{I} .22 \mathrm{~m}$ thick whose top lay at $c$. 2.Im OD. Approximately 2.Im of stiff red clay (possibly head) overlying soft clay with gravel lay below the Wentlooge Formation and above the Triassic rockhead at $c$. $-4.3 \mathrm{~m}$ OD. The gravel suggests the presence of Ipswichian (last interglacial) beach or shallow subtidal deposits, as described from Llanwern ${ }^{21}$ and elsewhere on the Caldicot Level. ${ }^{22}$

Triassic mudrocks and sandstones, cut by periglacial ice-wedge casts, outcrop on the lower foreshore at Magor Pill as a broad, low ridge rising to $c$. $-0.75 \mathrm{~m}$ OD (figs 2, 3). The pale green silts of the lower Wentlooge Formation above include a widely developed root horizon and many silted-up tidal creeks. Two bands of peat with a silt between, measuring I.47-I.70 m overall, crop out on a bold cliff and support a wide and almost level ledge (upper foreshore). A conventional radiocarbon age of $5680 \pm 70$ years BP (Beta-73058) was obtained for the base of the lowermost peat; the top of the uppermost deposit gave a conventional age of $2430 \pm 70$ years BP (Beta-73059). ${ }^{23}$ Hence the peat-silt complex (middle Wentlooge Formation) spans much the same interval as the main peat at Goldcliff $7 \mathrm{~km}$ to the south-west. ${ }^{24}$ Only the lowermost few decimetres of the pale green, upper Wentlooge silts are exposed on the coast, appearing toward the landward margin of the peat ledge beneath historical silts and a variable cover of contemporary mud.

The salt marsh at Magor Pill is divisible into at least three, offlapping morphostratigraphic elements (figs $2 \mathrm{~b}, 3$ ). The high marsh is underlain by mainly pale brown silts attributed to the Rumney Formation, of late seventeenth century or slightly later inception. ${ }^{25}$ Toward the landward margin of the peat ledge north-east of 
Magor Pill, the lowermost Rumney beds erosively overlie the upper Wentlooge Formation, but are themselves erosively succeeded by younger historical silts. The topmost few decimetres of the Rumney Formation, exposed on the clifflet to seaward of the high marsh, were only deposited after the nearby seabank had been set back in the late eighteenth or earliest nineteenth century. Accordingly, as at Rumney Great Wharf, ${ }^{26}$ the Rumney Formation may overlie a soil-capped cliff eroded back into the upper Wentlooge Formation (fig. 3). The grey silts of the intermediate marsh, also exposed on a seaward cliff, are assigned to the Awre Formation, ${ }^{27}$ deposition of which began in the late nineteenth century after an erosional phase. Beginning as a mudflat, the low marsh began to form in the present century, representing Allen and Rae's Northwick Formation. ${ }^{28}$

The palaeochannels of archaeological interest scour deeply into the Wentlooge Formation and, on the bedrock ridge, one of them cuts Triassic rocks with ice-wedge casts (figs $2 \mathrm{~b}, 3$ ). What we call the Eastern Palaeochannel (see below) lies to the northeast of Magor Pill. It cuts the lowermost upper Wentlooge Formation, together with the peats and silt of the middle division, bottoming out in the uppermost lower Wentlooge beds. Toward the landward margin of the peat ledge, the Eastern Palaeochannel is erosively overlain in places by the Rumney beds and in others by the Northwick Formation. Two phases - early and late - are recognized in the fill of the more extensive Western Palaeochannel, situated on the line of the pill but south-west of its present course. Far away, on the bedrock ridge, silts of the early phase are in erosive contact with the Trias. On the peat ledge, the Northwick Formation and, it is presumed, the Awre Formation are chiefly in erosional contact with the early phase deposits. However, near the sewer outfall, after storms have cleaned the ledge, the Rumney Formation is seen to truncate the early fill. The late fill is probably more complex in its relationships, although the available exposures were insufficient to resolve them directly. In terms of our evidence for age, the youngest parts of the late fill may be coeval with the older Rumney deposits.

\section{PROCESSES OF SALT MARSHES AND TIDAL CHANNELS}

The human forces that sought to mould and exploit the Severn Estuary Levels operated in the context of a complex and dynamic geological system. A close understanding of the system is crucial to attempts to interpret securely the meagre and much modified archaeological record that at so many places is all that survives. The Severn Estuary, on the exposed west coast of Britain, is exceptionally large and suffers an extreme tidal range of $14.8 \mathrm{~m}$ (Avonmouth); the tidal streams are vigorous and wave action is significant. Moreover, sea level in the area continues to rise ${ }^{29}$ and the tidal range, at least over recent decades, is increasing. ${ }^{30}$ The shores have responded to changes of sea level, climate and other factors by substantially altering their horizontal position, now building out, but at other times retreating. ${ }^{3 \mathrm{I}}$

Salt marshes and the genetically related tidal mudflats ${ }^{32}$ arise in the upper intertidal zone on the margins of estuaries and tidal embayments because it is only near the time of high tide that the water is still enough to release a deposit of silt sufficiently thick to survive the erosive tendency of the subsequent ebb. Geomorphologically, salt marshes are distinctive, chiefly in being dissected by 


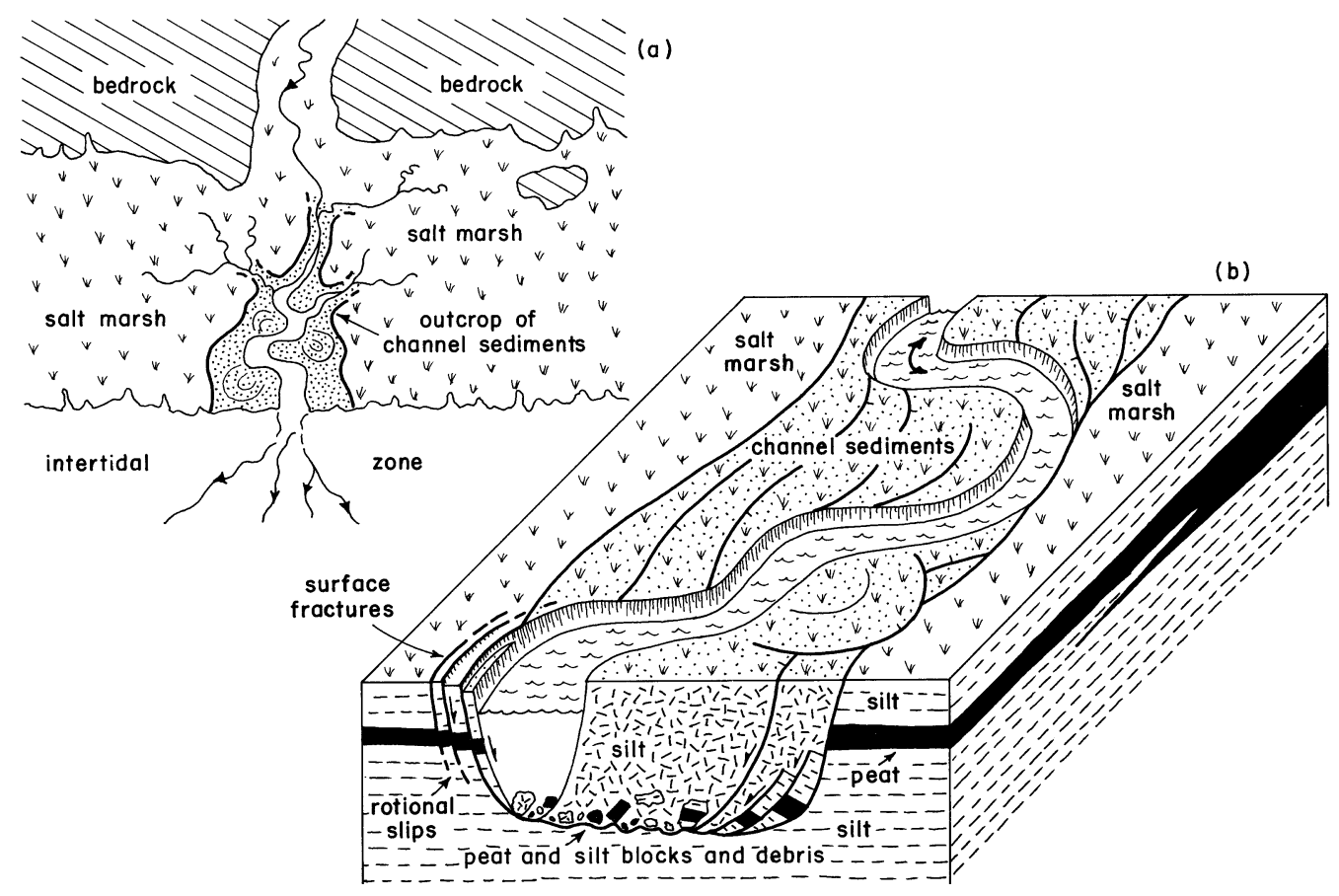

Fig. 4. A model for tidal channels and their sediments, (a) context, (b) character and stratigraphic relations

networks of branching channels that give the tide access to and exit from the comparatively level marsh platform at about the position of spring tides (fig. $4 \mathrm{a}$ ). Because of land-claim and agricultural modifications, however, we have almost no direct knowledge of the character of these channel networks in the Severn Estuary Levels, but it may be surmized that they resembled, although on a substantially larger scale, creek systems in the modern marshes on the open coast of Norfolk (fig. 5). At the coast, the channels may be expected to have been far apart, wide and deep; traced inland, they are likely to have become narrower, shallower and areally more numerous as they repeatedly branched in a tree-like manner toward each other and toward the landward edge of the marsh. Each network may be thought of as serving hydraulically a particular tidal 'catchment' on the marsh; some channels could have connected one catchment with an immediate neighbour.

In maintaining their position relative to changing sea level, salt marshes gain mineral sediment from the tidal waters and organic matter from the indigenous plants. According to general physical theory, ${ }^{33}$ the grain size of the mineral mud deposited from suspension on the marsh platform and in the channels should decline with increasing distance landward from the coast, which is the immediate source of the particles. This is because the sediment is advected with the tidal waters, and velocity and turbulence levels are expected to show some decline inland, promoting differential settling of the larger, faster sinking grains. Regarding the channels, the coarsest mud, and possibly some sand and even gravel, should occur in the mouths and lower reaches of the larger 


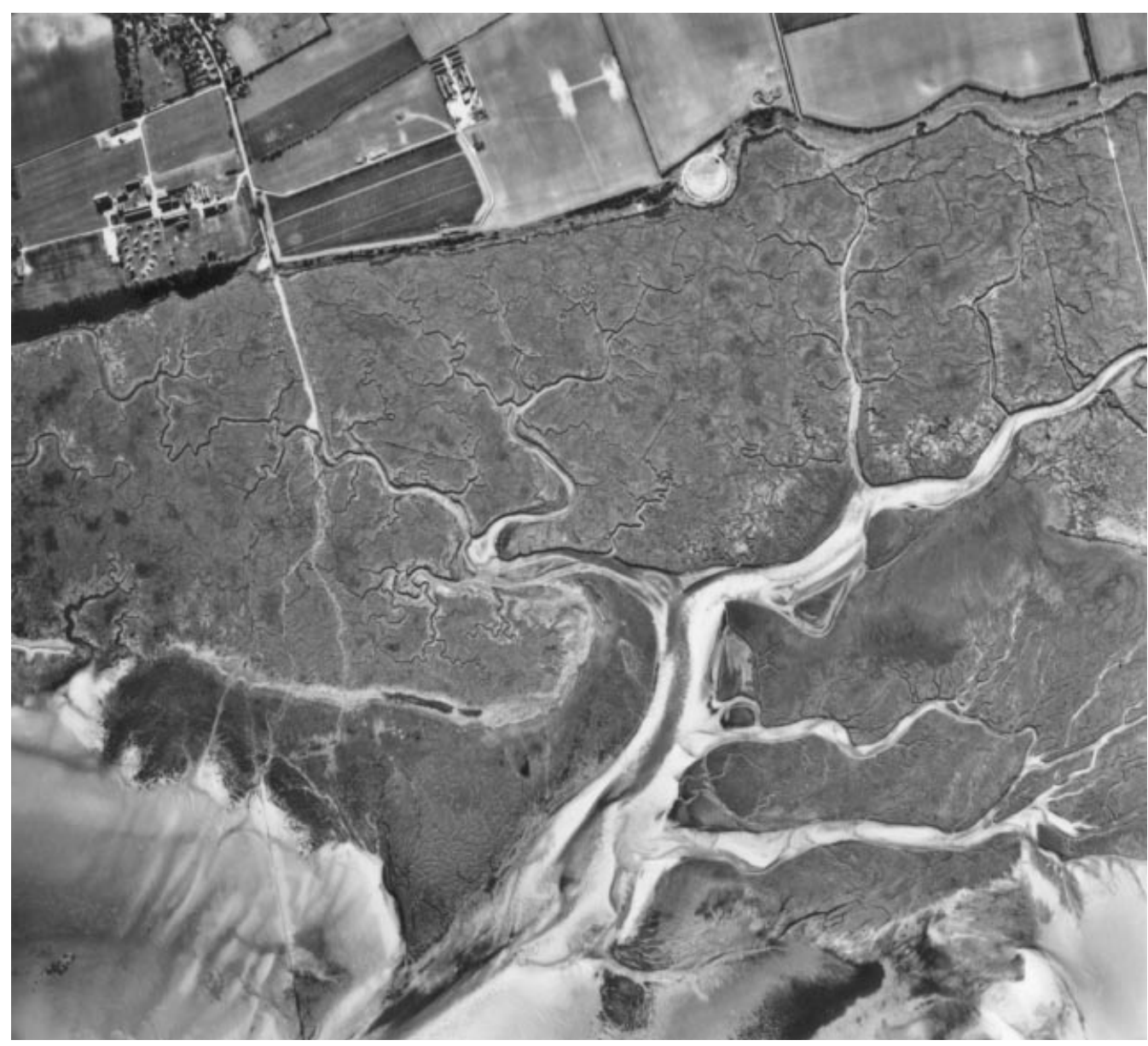

Fig. 5. Active salt marshes near Stiffkey on the Norfolk coast (area c. $1.8 \times 2 \mathrm{~km}$, north toward bottom). Photograph: Cambridge University Collection of Air Photographs. Copyright reserved

examples. Progressively finer grained muds should be found as the ramifying branches are traced inland. As explained below, we have exploited these expected trends in order to (a) correlate palaeochannel deposits visible only in disconnected outcrops, and (b) infer the position of the mouth. Thirdly, subtle differences in grain-size patterns could indicate changes of regime.

In large tidal wetlands, some tidal channels will also bear freshwater originating in the hinterland. Magor Pill is one of many large channels or pills surviving today on the shores of the Severn Estuary Levels which carry a small freshwater discharge. Although no longer in a fully natural state, the processes observed to shape them ${ }^{34}$ afford helpful clues to the recognition and understanding of fossilized tidal channels. These major channels (fig. 6) vary in plan from almost straight (e.g. Hill Pill, Avon), through moderately sinuous (e.g. Oldbury Pill, Avon; Goldcliff Pill, Gwent), to strongly 


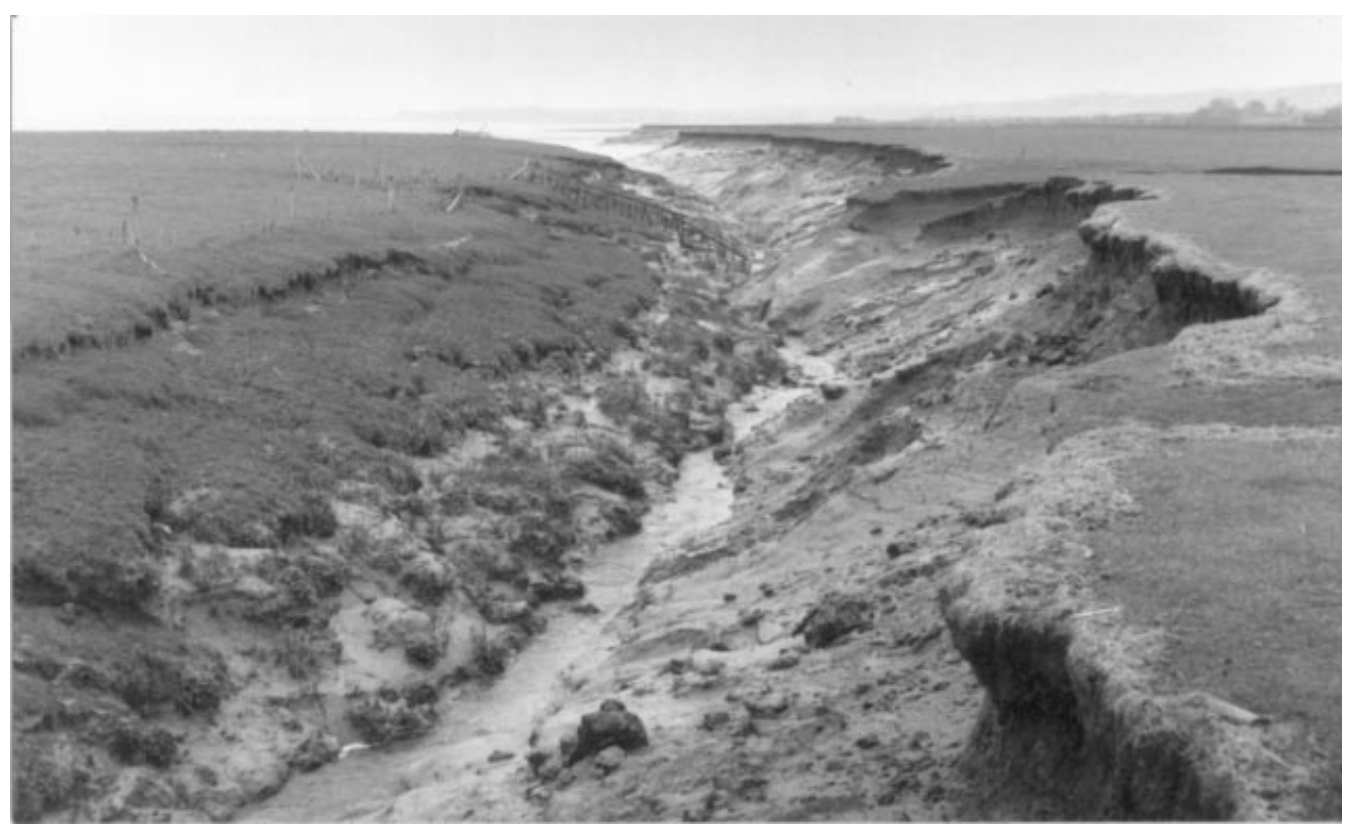

Fig. 6. Un-named pill east of Cone Pill, Lydney, Gloucestershire. View toward the south-west. Channel c. $8 \mathrm{~m}$ deep

meandering (e.g. Rhymney River, Cardiff; Berkeley Pill, Gloucestershire). Typically, channel widths at marsh level are a few to many tens of metres, increasing both toward the coast and with growing freshwater discharge. The depth below the marshland rim is rarely less than half the extreme tidal range, with the largest pills bottoming out below low tide level. In cross-section, the channels tend to be symmetrical and almost Vshaped (fig. 6), even within sharp bends, with side slopes of $30^{\circ}-50^{\circ}$. The channels are much reduced seaward of the marsh, and in many cases the discharge simply spreads out over the mudflats or sandlfats as shallow, branching washes, or even as an unconfined sheet. Hence significantly incised channels are found only in embanked wetlands and in the salt marshes that fringe them; where a deep palaeochannel is exposed at outcrop, it may be assumed to have ranged down from the level of a contemporary natural or embanked marsh.

Although more slowly than rivers, because of the strong, cohesive banks, tidal channels wander laterally as the result of net erosion on the outsides of bends and a harmonious net deposition on inner banks. Consequently, each pill fashions around itself an erosively bounded complex of channel deposits (fig. 4a, b), formed from a number of sediment units of a range of ages and themselves likely to show chiefly erosional (or mechanical, see below) relationships. An active channel may partly silt up if the freshwater discharge is reduced in scale, a process that can arise naturally but is more likely to have a human cause. It may fill completely if the freshwater flow is terminated because of either diversion at the coast or rerouting after land-claim or a phase of improvement. 


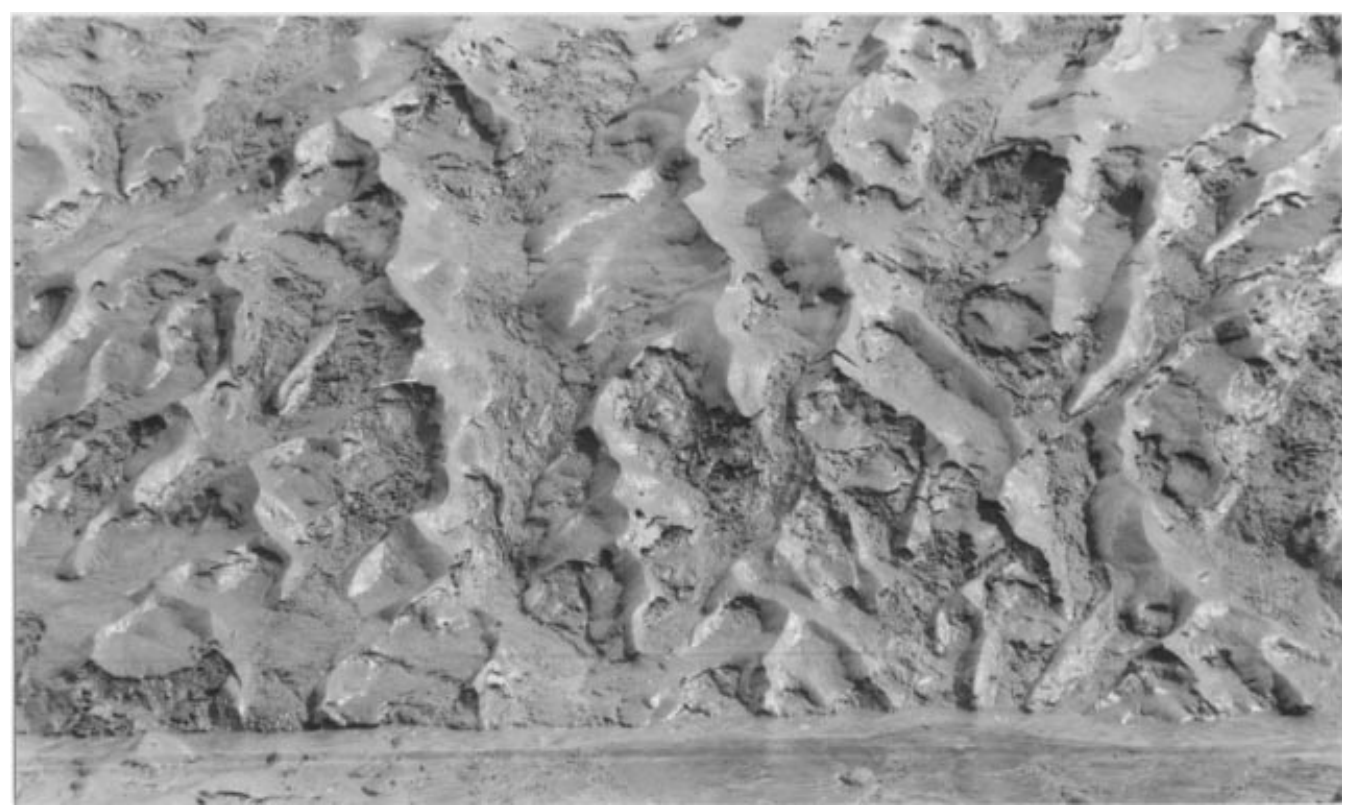

Fig. 7. Mudflows in Littleton Pill, Littleton on Severn Gloucestershire. About $5 \mathrm{~m}$ of the bank is visible above the freshwater stream in the bottom

The tidal discharges in and out of a pill vastly exceed the freshwater flow. How then is dynamic equilibrium sustained, so that the channel endures, albeit changing in configuration, over some substantial period? Silt is heavily deposited on the sides around high-water slack, when the pill is full to near or above the rim. As the tide falls, and the sloping sides emerge into the less-supportive air, gravity-driven massmovement processes acting on a range of scales begin to carry sediment downward toward the channel bottom. The smallest and most frequent collapses are mud flows (fig. 7), originating in metre-scale, bowl-like depressions, which transport semifluid mud down the furrowed sides. ${ }^{35}$ Larger in scale, and operating over months to years, are rotational slips carrying deep but narrow slices of sediment downward on bowl-shaped to cylindrical fault surfaces (figs 8, 9). As the sediments affected generally are relatively strong - stiffened silt and peat - the slices tend to retain stratigraphic integrity, although many disruptive fractures may arise within a slice during its episodic back-tilting and descent. Bedding in the softer sediments may become folded as the mass slumps. Typically, striations (slickensides) parallel with slipping are developed on the failure and more substantial fracture surfaces (fig. IO). Fault surfaces normally emerge either low down on the side of the pill or at its bottom. Occasionally, tall undercut banks fail by toppling outward. The fate of these variously displaced and weakened masses is to be gradually broken down at the channel bed by waves and currents into progressively smaller lumps, which become increasingly rounded in the process. Peat beds, however, are not easily broken up, and tend to survive as large blocks and almost buoyant rafts. Although relatively small, the continuous freshwater flow, combined with the last of the tidal 


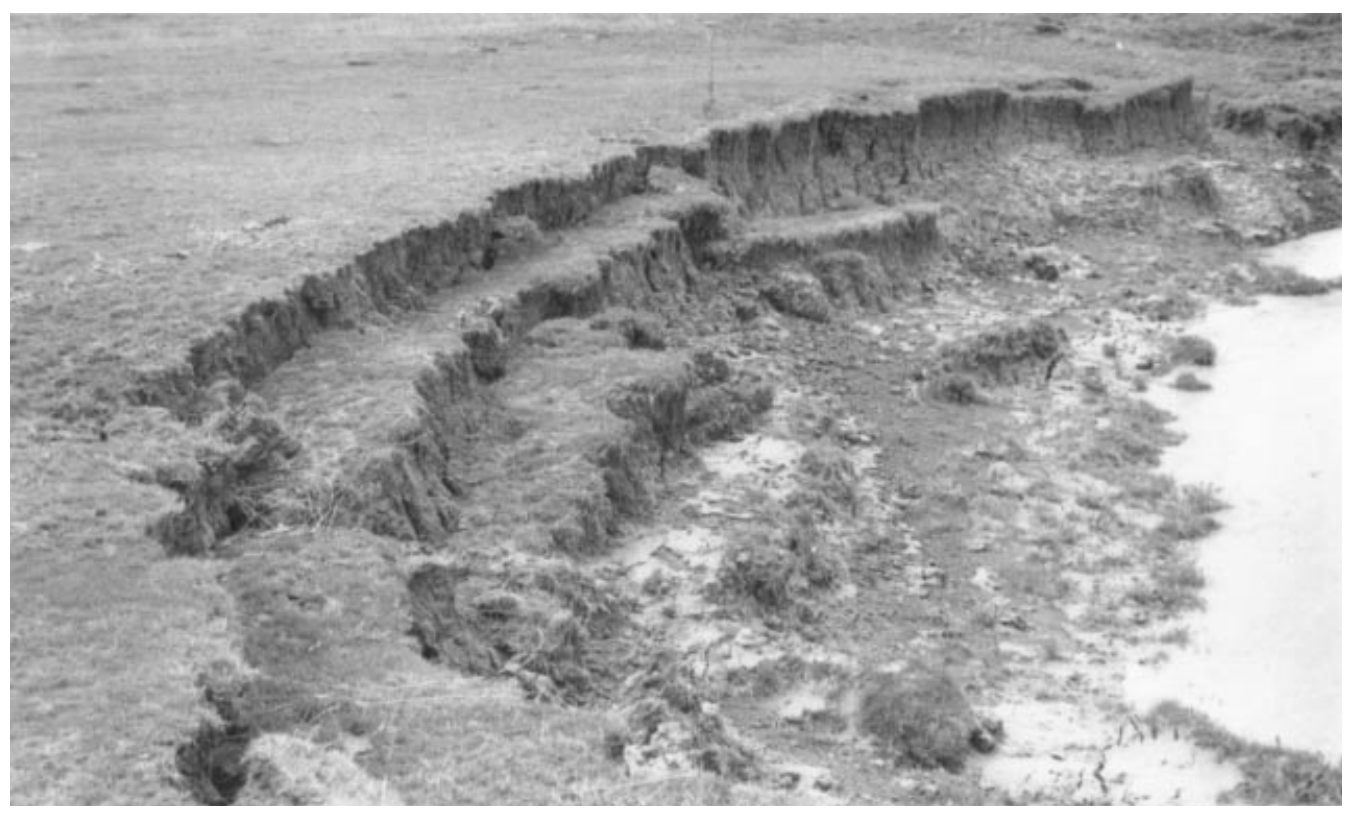

Fig. 8. Rotational slips on bowl-shaped fault surfaces, banks of Berkeley Pill, Berkeley, Gloucestershire. Spade $0.94 \mathrm{~m}$ tall for scale

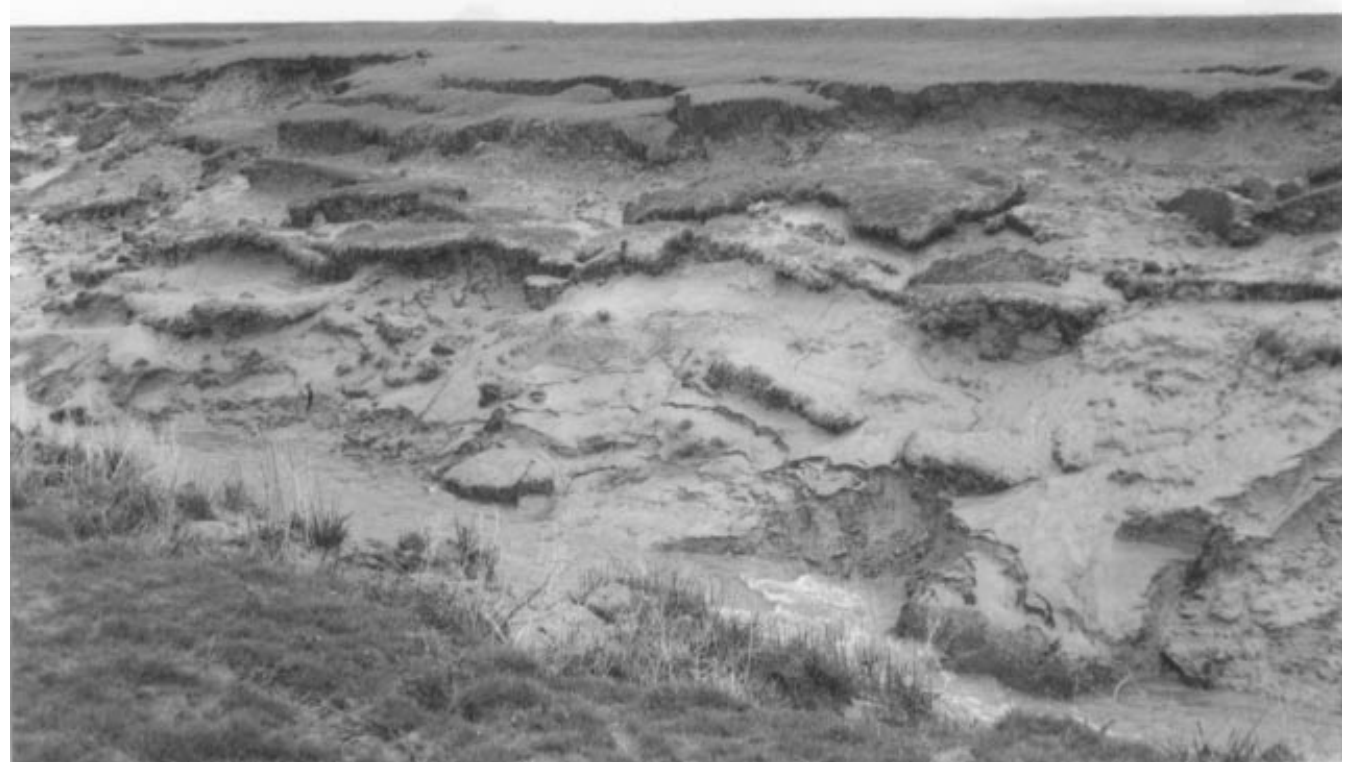

Fig. 9. Rotational slips on cylindrical fault surfaces, Cone Pill, Lydney Gloucestershire. Channel c. $8 \mathrm{~m}$ deep 


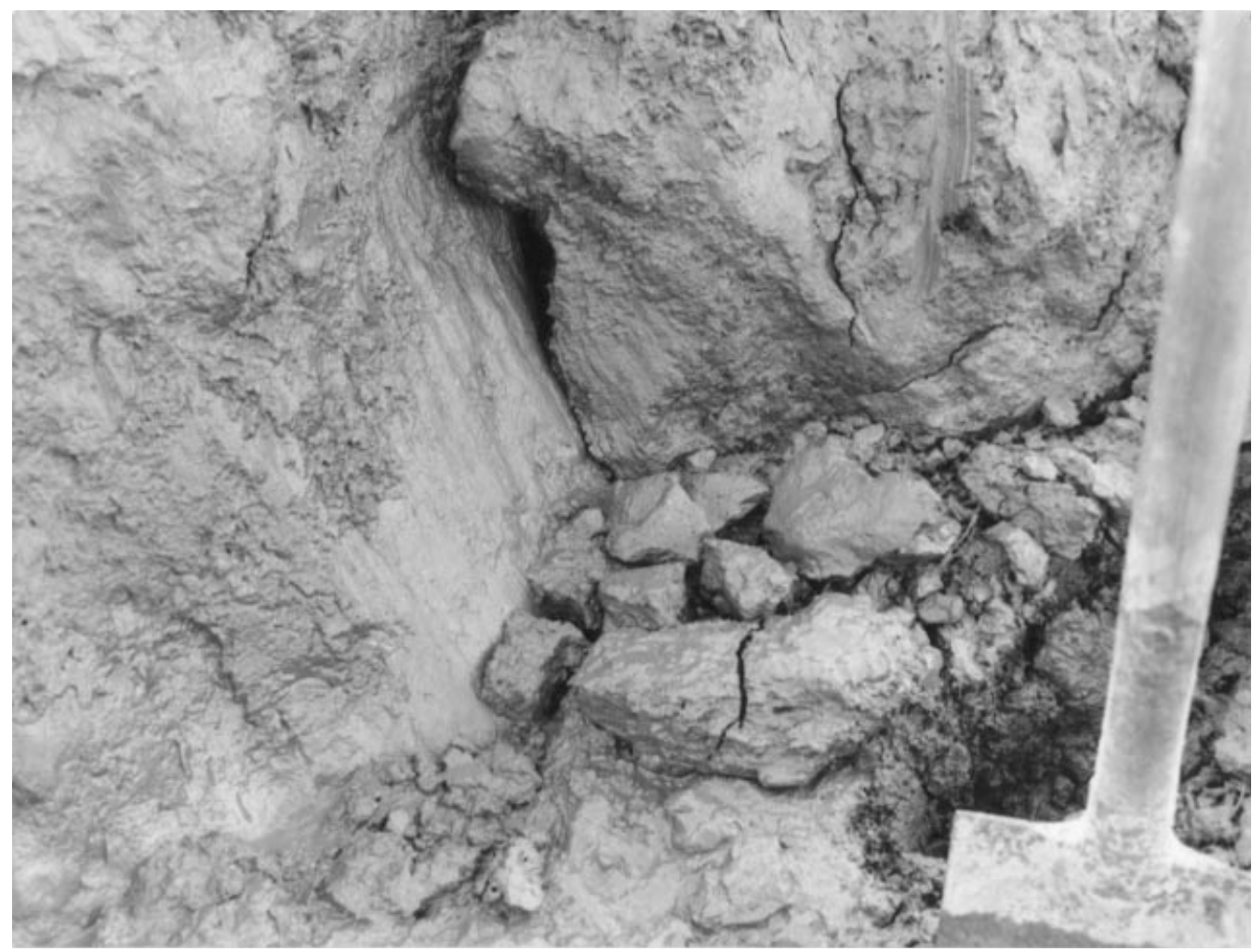

Fig. Iо. Vertical striae (slickensides) on fault surfaces associated with rotational slips, Berkeley Pill, Berkeley, Gloucestershire. Spade blade 0.I4m across for scale

water, performs at low tide the final, vital task of removing axially along the channel the collapsed and fragmented debris. Thereby the channel retains dynamic equilibrium.

Hence in the sediments fashioned by tidal channels (fig. 4b), we expect to find: (a) mechanical as well as erosional sedimentary contacts between bodies of tidal silt, (b) slickensides on surfaces of mechanical contact, (c) collapsed slices and blocks of partly disrupted sediment, (d) disturbed and folded bedding, and (e) especially along erosional contacts, rounded clasts of sediment derived from both older channel deposits and the beds which host the channel deposit as a whole. In the Severn Estuary Levels, the slices and blocks should include peats from the middle Wentlooge Formation.

\section{DEPOSITIONAL PROCESSES AND ARTEFACTS}

The natural processes and their effects have important implications for coastal archaeology. ${ }^{36}$ Artefacts preserved at any depth in palaeochannel deposits may have been either (a) deliberately emplaced (e.g. fish weirs), (b) directly discarded from 
boats, (c) directly discarded from landing places or settlements on the banks, (d) displaced downward (possibly with building and other structural materials) together with archaeological strata from primary contexts as a consequence of bank collapse, (e) washed in (transposed) from landward, or (f) washed in (transposed) from seaward by tidal currents or during storms. Only in the first three cases are the artefacts in a primary (but not terrestrial) context; they should not ordinarily display water wear but, as Hawkins showed, their altitudinal position will require careful assessment. ${ }^{37}$ Displaced artefacts may show signs of weathering acquired while in the primary context but should be neither water-worn nor water-sorted. Unless transport was brief, evidence of sorting and abrasion should accompany transposed artefacts. Except where there are peats, generally of limited stratigraphical distribution, Flandrian estuarine beds are notoriously difficult to date physically. Palaeochannel deposits, however, are likely to contain twigs and branches swept down in storms from hinterland trees.

\section{THE EASTERN PALAEOCHANNEL (IRON AGE)}

This almost straight feature, 7-26m wide and with branches joining from the north and south, ranges eastward across the peat ledge before turning sharply to the south-east where, coincidentally, it breaches the cliff formed by the peat (fig. 2b). Together with the branches, which appear contemporaneous with it, the channel is filled with locally laminated, brownish green sandy clayey-silts. Samples for grain-size analysis were collected from the main palaeochannel and its northern tributary (fig. I Ia). Their mean grain size in the main deposit varies from $\mathrm{I} 6 . \mathrm{I}-25.3 \mu \mathrm{m}$ and averages $\mathrm{I} 9.3 \mu \mathrm{m}$; the branch gave an average of $20.3 \mu \mathrm{m}$ and a range of $16.4-23.1 \mu \mathrm{m}$.

The grain-size distribution curves (fig. I2a) can be divided between three patterns (fig. I 2b). ${ }^{38}$ Pattern I has a single mode at c. $20-50 \mu \mathrm{m}$; on the finer limb, is a shoulder (c. Io $\mu \mathrm{m})$ representing a sub-population of smaller grains. In pattern III, roughly equal modes at $c$. Io $\mu \mathrm{m}$ and $c .20-30 \mu \mathrm{m}$ are seen. The population of larger grains in pattern IV is represented only by a shoulder on the coarser limb. The palaeochannel is exposed over too short a distance for a clear textural trend to be evident from the fill, but there is a hint of downstream coarsening (figs I I b, I2b).

Locally, lumps of silt bound by fine roots (possibly marsh turf) are embedded in the fill, which is broken by numerous, slickensided surfaces (fig. I3), consistent with mass movements on the channel sides (fig. Io). Features of collapse are especially clear at the seaward margin of the upper foreshore, where the palaeochannel turns and bottoms out on the cliff in the lowermost peat and uppermost lower Wentlooge Formation. Wave action has picked out parallel, steeply dipping fractures that cut the exposed upper surface of the peat on the outside of the bend (fig. I4). These appear to be the precursors of actual faults. The slides themselves, reminiscent of failures affecting contemporary pills (fig. 8), lie embedded within the channel fill as rotated and back-tilted, silt-peat slices resting on concave-up faults (fig. I5).

Iron Age artefacts occur in the fill of the palaeochannel and its northern tributary (fig. 2b). Near their confluence, we recovered the jaw of an adult horse and fire-fractured pebbles of quartzite and vein-quartz. Iron Age pottery had earlier been described by Whittle et al. from this same place. ${ }^{39}$ Their excavation of the tributary (fig. $2 \mathrm{~b}$ ) revealed 


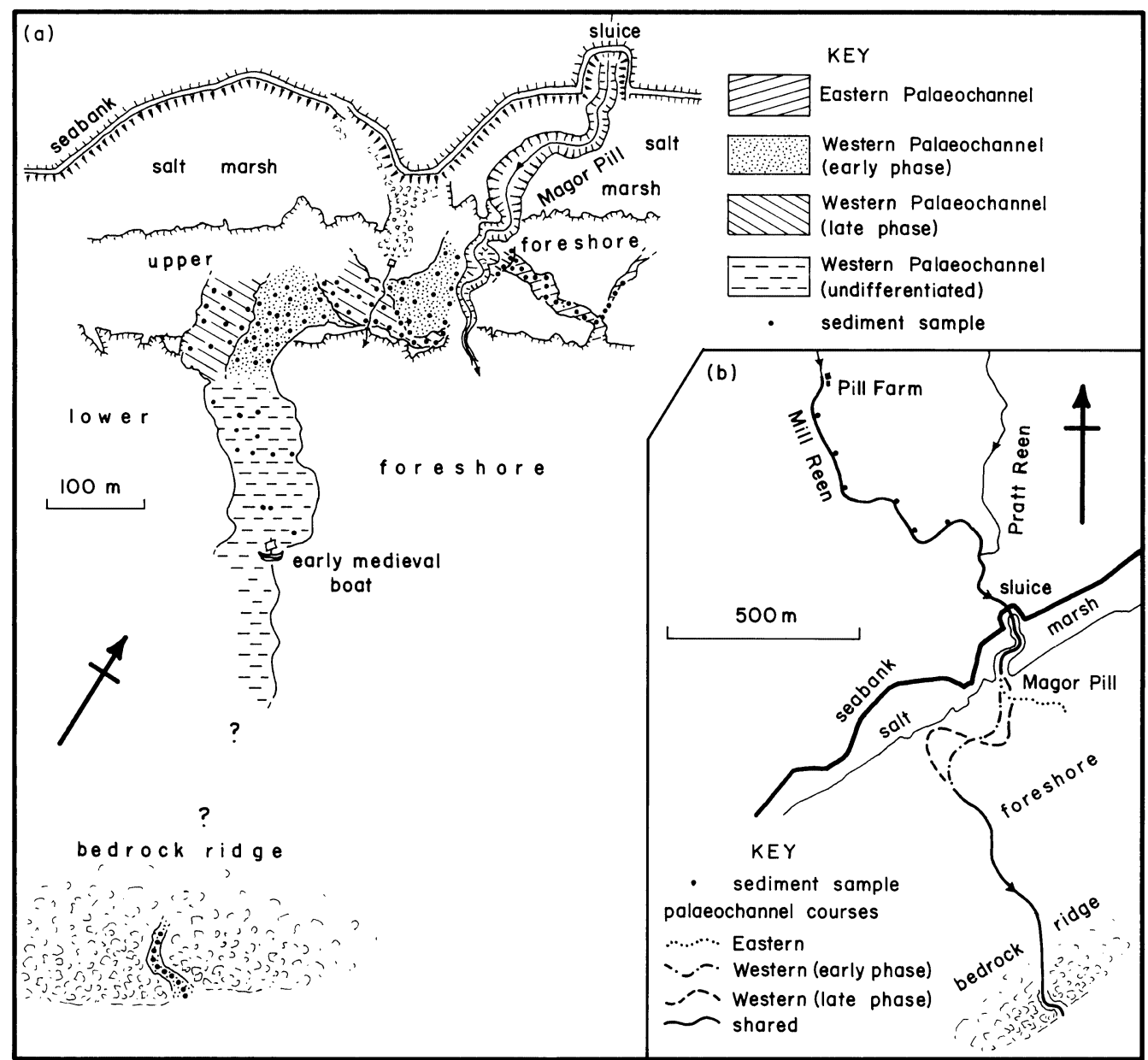

Fig. I I. Locations of sediment samples from palaeochannels at Magor Pill (a) foreshore samples, (b) Samples from Mill Reen; 'standard' palaeochannel courses below Pill Farm, for the purpose of assigning a downstream position to sediment samples

more Iron Age material, including bones (horse, sheep/goat), a shaped wooden peg, and substantial sherds from numerous pottery vessels, attributed to the first century BC. In view of the size and freshness of the sherds, the assemblage was probably discarded, at a number of points, directly into the creeks.

The Eastern Palaeochannel is exposed today at a low erosional level, equivalent to the top of the peat, of early Iron Age date (see note 23). Late Iron Age rubbish would have been discarded from an occupation, no longer surviving, on a marsh lying significantly higher $(c .2 .85 \mathrm{~m})$, judging from the thickness of the upper Wentlooge Formation at the borehole site (fig. 3) and the most plausible date for land-claim, in the Roman period. $4^{\circ}$ 


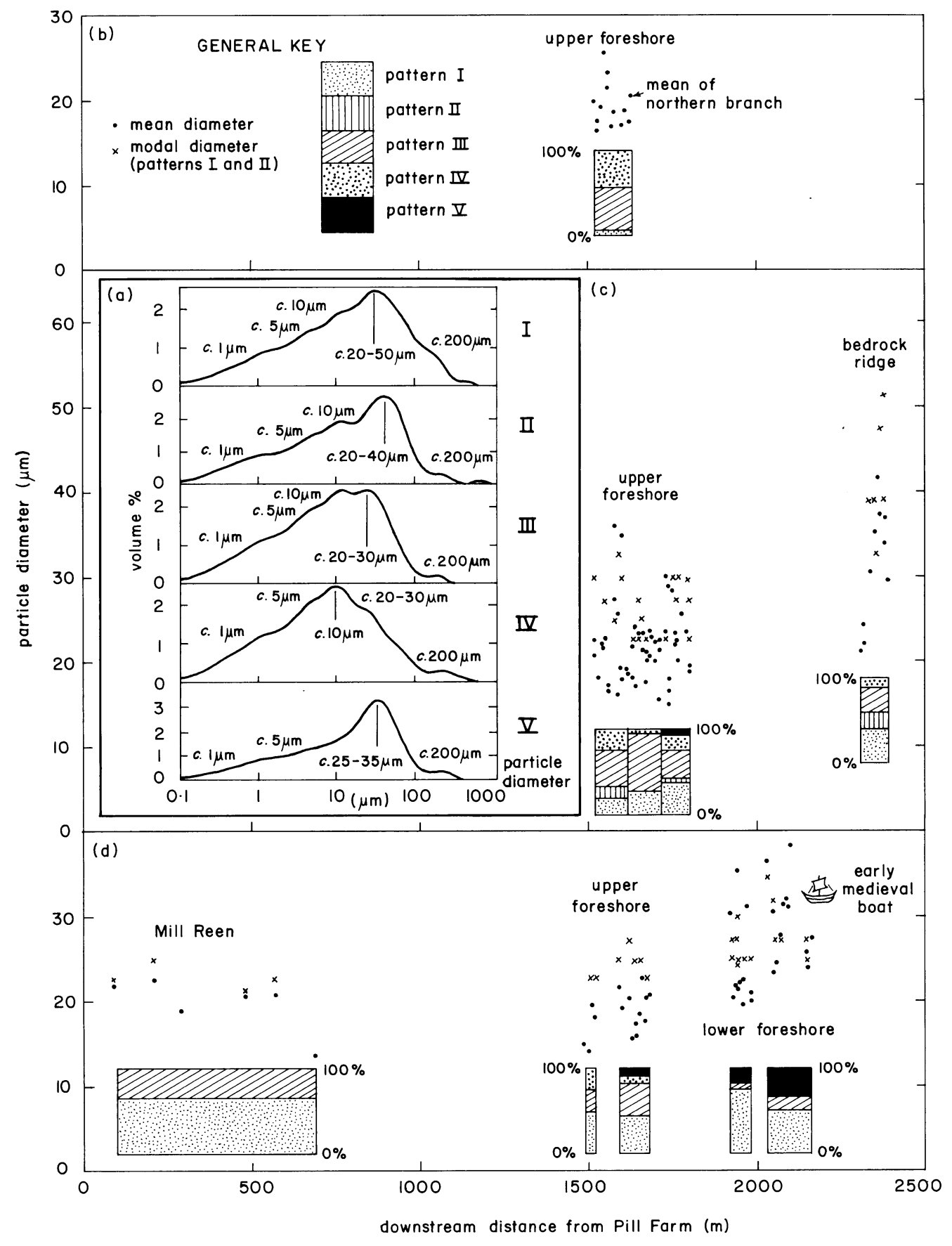

Fig. I2. Textural features of palaeochannel sediments, (a) patterns of grain-size frequency distribution as exemplified by selected samples. Grain size-distance trends in (b) Eastern Palaeochannel, (c) Western Palaeochannel (early phase), and (d) Western Palaeochannel (late phase) 


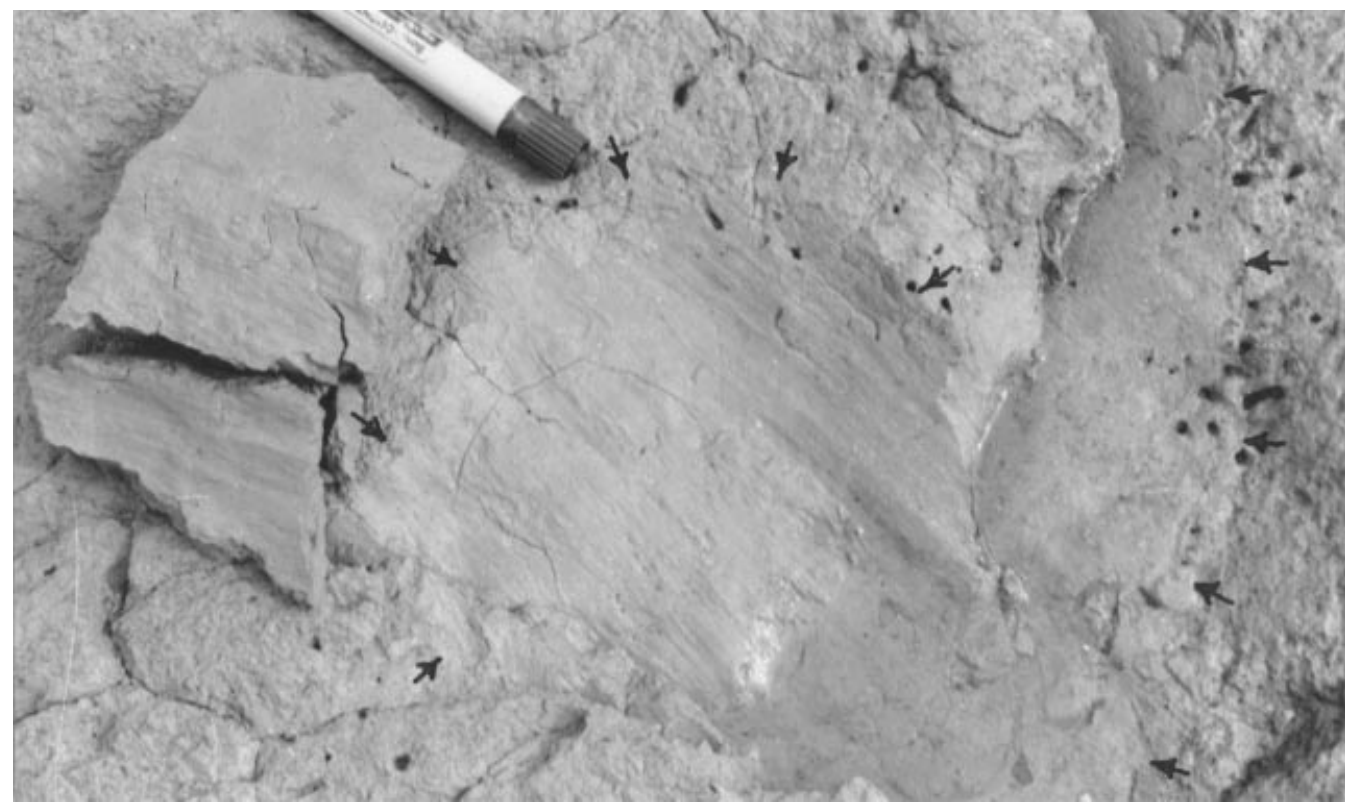

Fig. I3. Slickensided failure surface (arrowed), Eastern Palaeochannel. Spirit marker for scale

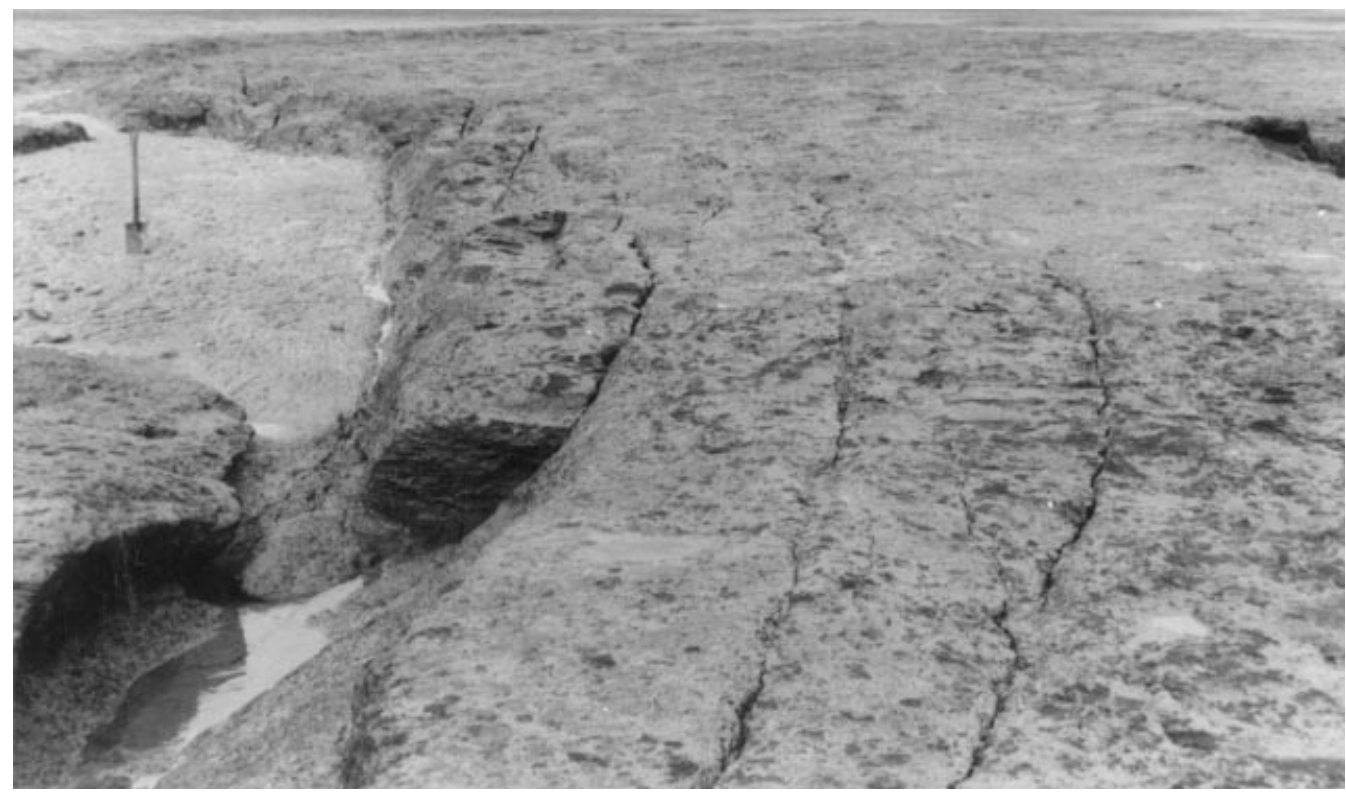

Fig. I4. Channel-parallel failure surfaces (dip to left) in middle Wentlooge Formation intersecting surface of peat ledge, left bank of Eastern Palaeochannel (to left). Spade $0.94 \mathrm{~m}$ tall for scale 


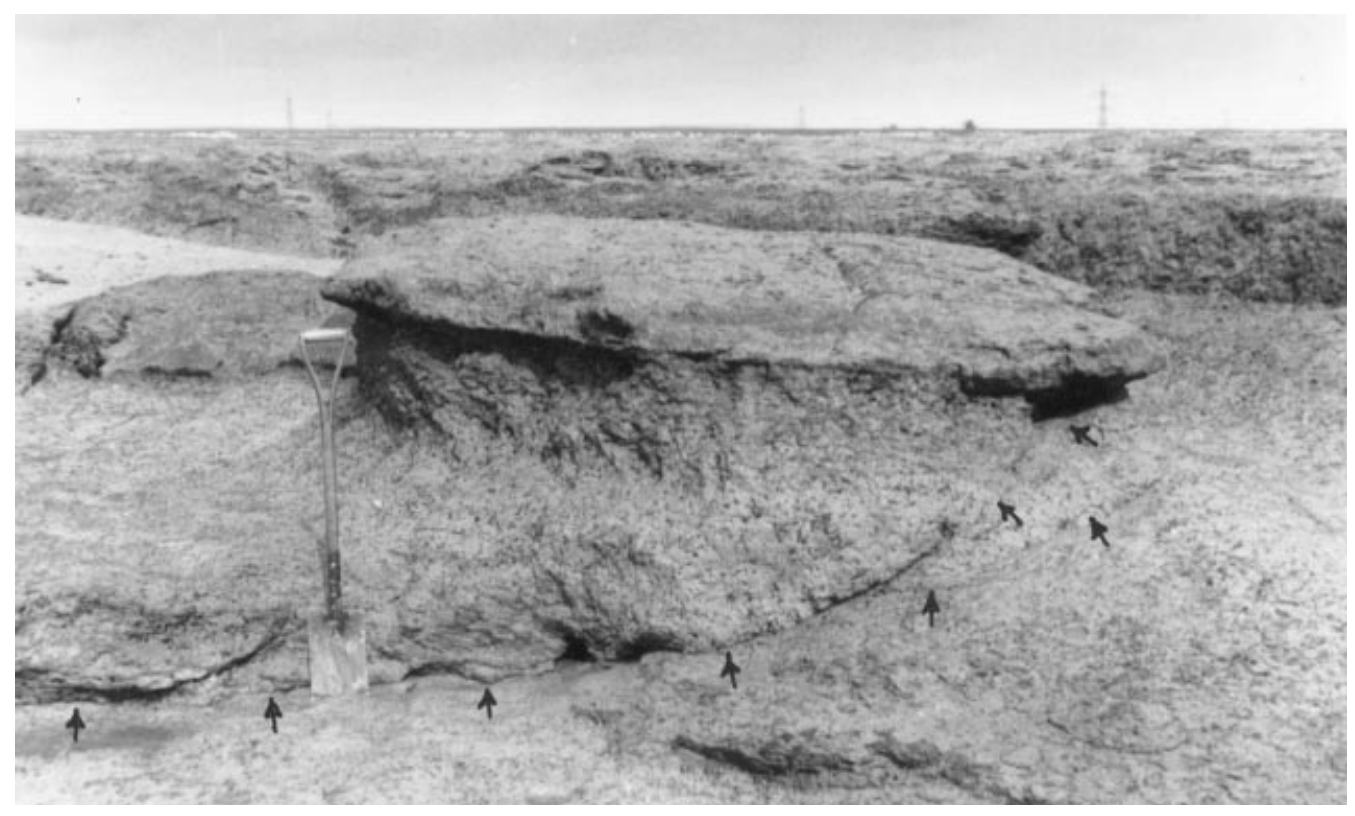

Fig. I5. Back-tilted slice of silt and peat (middle Wentlooge Formation) on concave failure surfaces (arrowed), left bank of Eastern Palaeochannel. Spade $0.94 \mathrm{~m}$ tall for scale

THE WESTERN PALAEOCHANNEL (ROMAN-EARLY MODERN)

\section{Early phase}

The Western Palaeochannel as a complex can be traced over a great double loop from modern Magor Pill below its outfall, then into the embayment skirted by the seabank to the west, and finally through a gap in the peat ledge and across the lower foreshore to the bedrock ridge (fig. 2 b). Its width is of the order of Ioom. Except where overlain by historical or contemporary deposits, the silts forming the fill are visibly in sharp, erosional contact with either the Trias or the Wentlooge Formation. As at the Eastern Palaeochannel (fig. I4), steep fractures parallel with the contact have been etched out on the nearby peat ledge, and displaced slices and blocks of silt and peat occur nearby in the fill (figs $2 \mathrm{~b}, \mathrm{I} 6$ ). Irregular lines and clusters of such presumed bank-related masses, supplemented by the contents of test-pits dug through the cover of standing water and loose sediment, largely define the contact on the lower foreshore (fig. 2b). The sand cover was too thick for the palaeochannel to be reliably mapped over a gap of about $250 \mathrm{~m}$ between the last peat rafts and the bedrock ridge, where the erosional relationship is again visible.

The deposits attributed to the early phase are brownish green silts exposed at the bedrock ridge and over the upper foreshore, on the inner sides of the palaeochannel loops (fig. 2b). Similar silts, free of roots in contrast to the Wentlooge Formation at this erosional level, were seen at a few points within the bounds of the palaeochannel on the largely obscured lower foreshore, but could not be mapped more widely. 


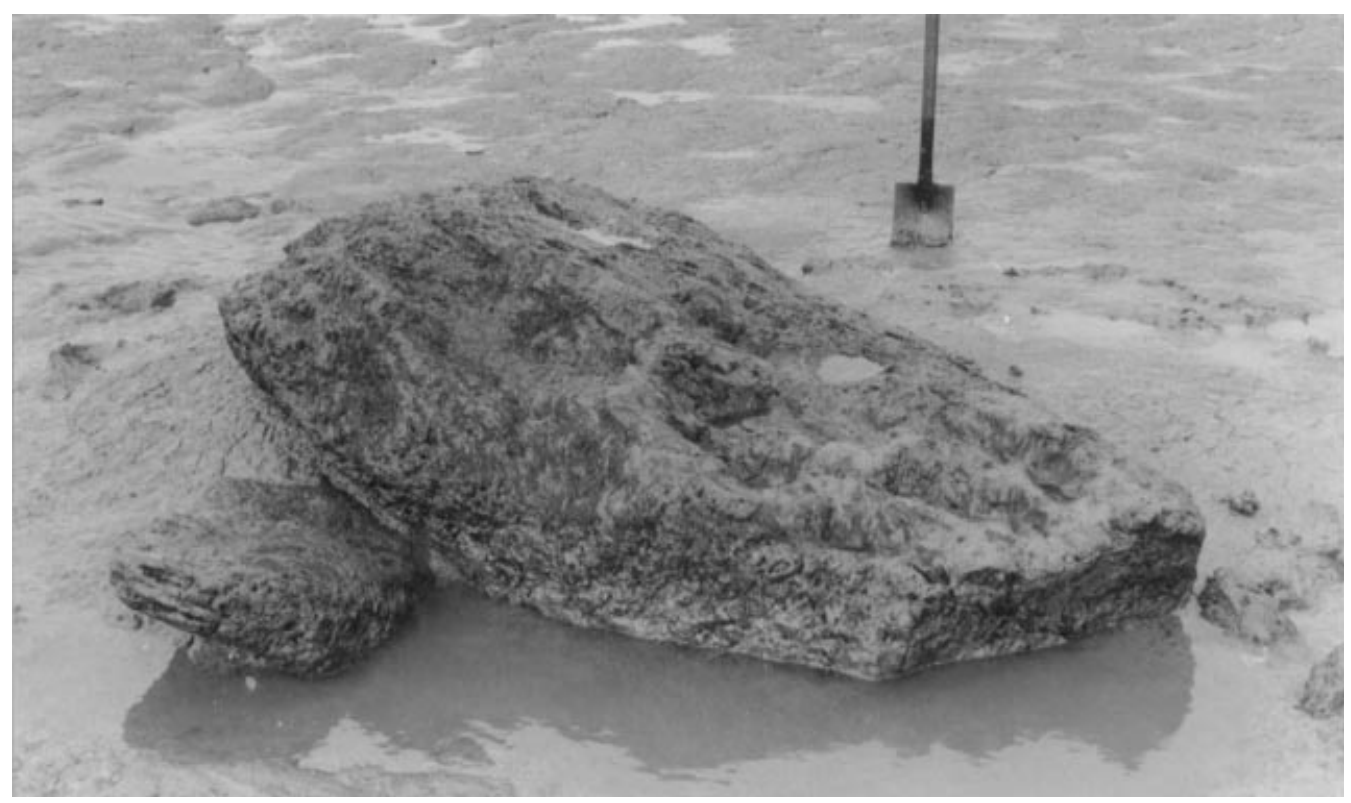

Fig. I6. Tilted peat blocks emerging from silts of Western Palaeochannel (early phase). Spade blade $0.14 \mathrm{~m}$ wide for scale

Only to the west of the sewer outfall could internal contacts - generally mixed erosional-mechanical - be mapped and sub-units (A-D) identified (fig. 2b). Slickensided surfaces are numerous and much of the bedding is fractured, folded and back-tilted. A drifted, bark-covered branch of oak dug from near the palaeochannel margin east of the outfall gave a conventional radiocarbon age of $1580 \pm 60$ years BP (Beta-71596).4 ${ }^{4}$ From sub-unit $\mathrm{B}$ to the west was excavated bark-covered, hazel roundwood yielding a conventional age of $\mathrm{I} 280 \pm 70$ years BP (Beta-7I598). Conventional ages of I $240 \pm 70$ years BP (Beta-7I595) and IOIO \pm 50 years BP (Beta7I597) were obtained from drifted pieces of bark-covered hazel preserved at separate places within sub-unit D; locally, these silts are mottled brown, similar to the colouring of the late phase (see below). The palaeochannel fill at the bedrock ridge lacked contemporaneous artefacts or dating evidence but was crossed by two sets of wooden stakes (see below). A sample from the outermost set, of split oak, judged to be the older, gave a conventional radiocarbon age of $1080 \pm 40$ years BP (Beta-92999).

On the upper foreshore, the fill consists of sandy clayey-silts which increase downstream in mean grain size and the proportion of samples with pattern I (figs I I, I2c). Two patterns not found in the Eastern Palaeochannel make their appearance (fig. I2a). Pattern II, resembling the much more common pattern I, has a minor mode at c. Io $\mu \mathrm{m}$ but a dominant one at $20-40 \mu \mathrm{m}$. Pattern V, limited to one sample, is unimodal, with a narrow peak and concave, shoulderless limbs. Between I 520-I630m downstream in the early phase - the same span as the Eastern Palaeochannel - the range in mean grain size is $16.0-27.2 \mu \mathrm{m}$ and the average $20.2 \mu \mathrm{m}$ (excluding two seemingly aberrant coarse samples). The palaeochannel fill at the bedrock ridge is on the whole coarser grained than upstream, consisting of brownish green, sandy clayey-silts with some 


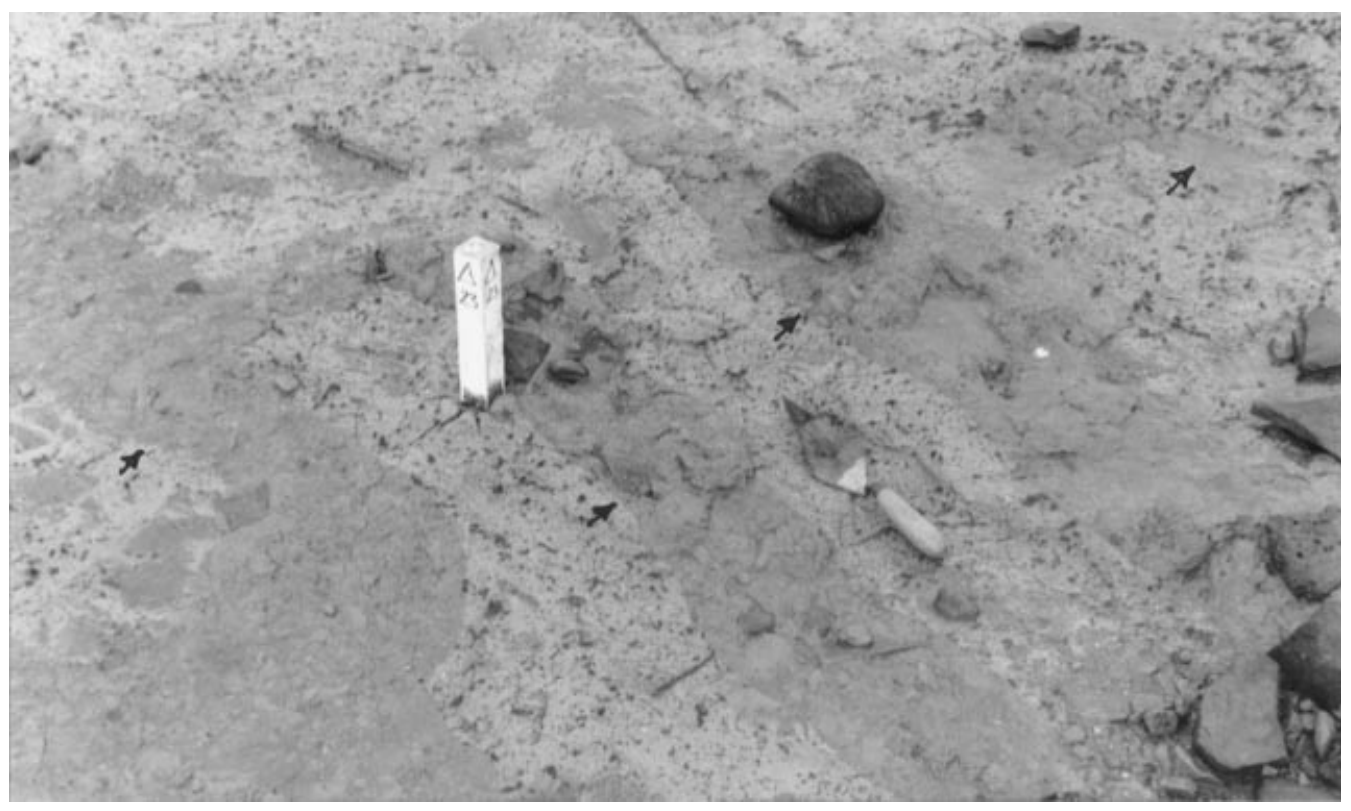

Fig. 17. Silts occupying flow-parallel, erosional grooves (arrowed) cut in rootbearing silts of lower Wentlooge Formation. Base of Western Palaeochannel (late phase). Trowel $0.28 \mathrm{~m}$ long for scale

clayey sandy-silts. Samples of patterns I and II are together more common than upstream, but III and IV continue to be represented. Throughout the outcrop, the modal grain size (patterns I and II), like the mean, increases downstream (fig. I2c).

\section{Late phase}

These deposits are pale brown silts, strikingly different in colour from the early phase, and accumulated in a channel that had grown more sinuous (fig. $2 \mathrm{~b}$ ). Their bedding is generally disturbed, but many original dips inward to the channel axis are evident. The silts are in erosional contact with the Eastern Palaeochannel to the east of Magor Pill and with the Wentlooge Formation to either side of the sewer outfall. Between outfall and pill the channel bottom is exposed, the brown silts, accompanied by peat and silt clasts, water-worn pebbles and cobbles, lumps of stone, and occasional artefacts, infilling flowparallel grooves scoured into the Wentlooge silts (fig. I7), as in modern rivers with beds of rock or stiff clay. ${ }^{42}$ The pebbles and cobbles are of various lithologies, many of which are matched in the Pleistocene gravels of the outer Severn Estuary. Some of the lumps of stone, measuring up to $0.35 \mathrm{~m}$ in length, show signs of water-wear, but most apparently were roughly quarried. Further south-west, where the channel begins to break away from the peat ledge, the fill cuts the early phase and lies erosively, to the accompaniment of bank fractures and collapses, against the Wentlooge Formation (fig. I8). Internal erosional contacts strewn with coarse debris similar to that just described were observed here. Pale brown silts were widely visible on the lower foreshore and were detected in the great majority of test pits within the bounds of the complex as defined by peat rafts. 


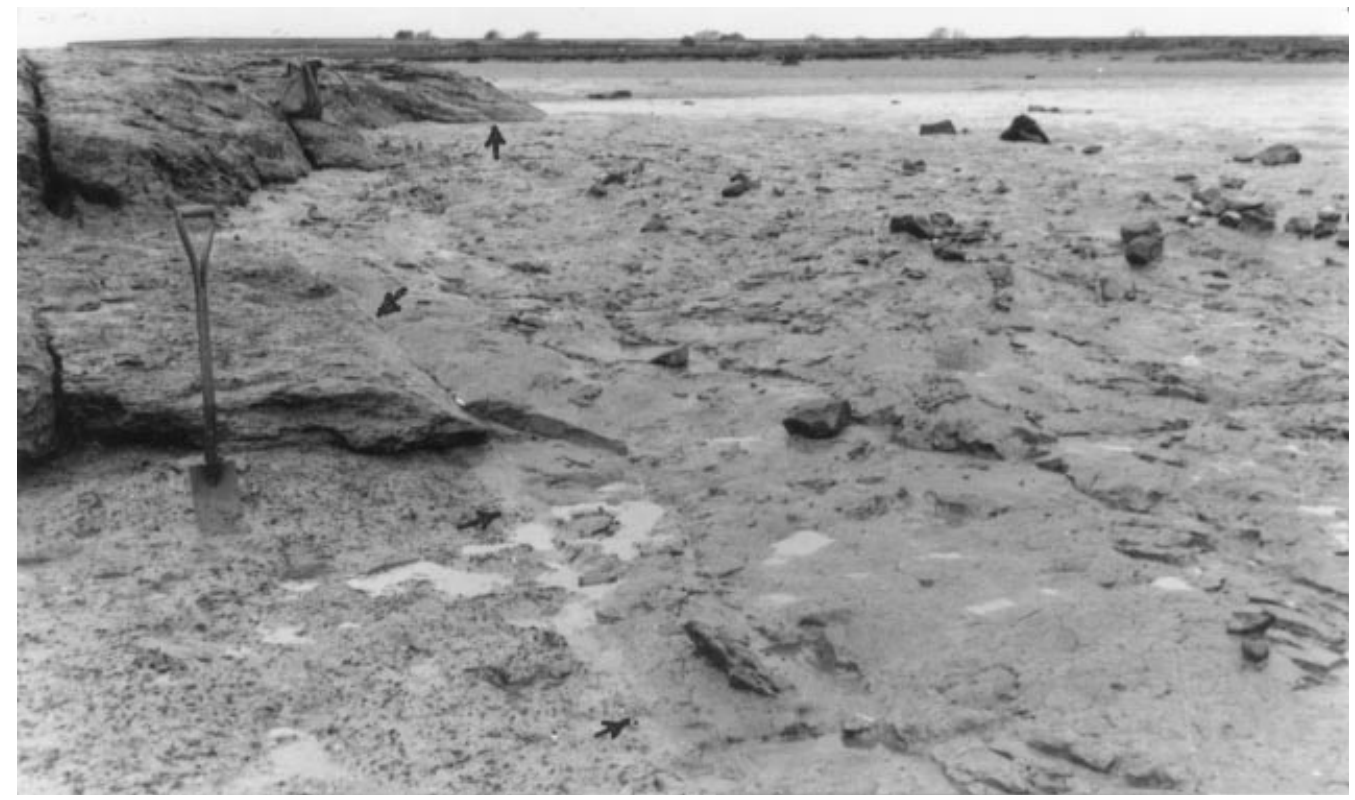

Fig. I8. Western Palaeochannel (late phase) showing a moderately dipping, erosive bank (arrowed) where it breaches the peat ledge and lower Wentlooge Formation. Spade $0.94 \mathrm{~m}$ tall for scale

There is some physical evidence for the age of the pale brown silts. A drifted piece of bark-covered willow, excavated from the inner peat ledge in an axial position within the fill (fig. 2b), gave a conventional radiocarbon age of $140 \pm 70$ years BP (Beta-7I 594).43 A hurdle-like structure (see below) in the silts on the lower foreshore gave $22 \pm 50$ years BP (Beta-7200I).

As with the early phase, the pale brown silts exposed at the level of the peat ledge and on the lower foreshore increase in coarseness with distance along the palaeochannel (figs I I, I2a, d). They are overwhelmingly sandy clayey-silts, accompanied by a very few clayey sandy-silts, similar in mean and modal grain size to the early phase deposits. The phases differ significantly, however, in the textural patterns represented. Pattern I is more prevalent in the late phase, with fewer samples of patterns III and IV, and no cases of pattern II. Distributions of type V achieve a prominence (seven samples) lacking in the early phase and Eastern Palaeochannel, their proportion increasing downstream. Exposed in the banks of Mill Reen downstream from Pill Farm (fig. IIb), and also attributed to the late phase, are pale brown,tidal silts with sponge spicules and mixed estuarine-open marine diatoms and foraminifera. These deposits, chiefly of pattern I, are about as coarse as the silts from the peat ledge, more than a kilometre downstream.

At three places, stout wooden stakes, in lengthy double rows a metre or so apart, had been driven upright into the sediments of the Western Palaeochannel (fig. 2b). Two of these, one of split oak (see above) and the other of roundwood, occur at the bedrock ridge. The third, also of roundwood, crosses the edge of the largest gravel sheet.

Embedded in the late phase deposits of the Western Palaeochannel are pieces from hurdles of woven roundwood (fig. 2b). Associated with coarse debris near the base of the 


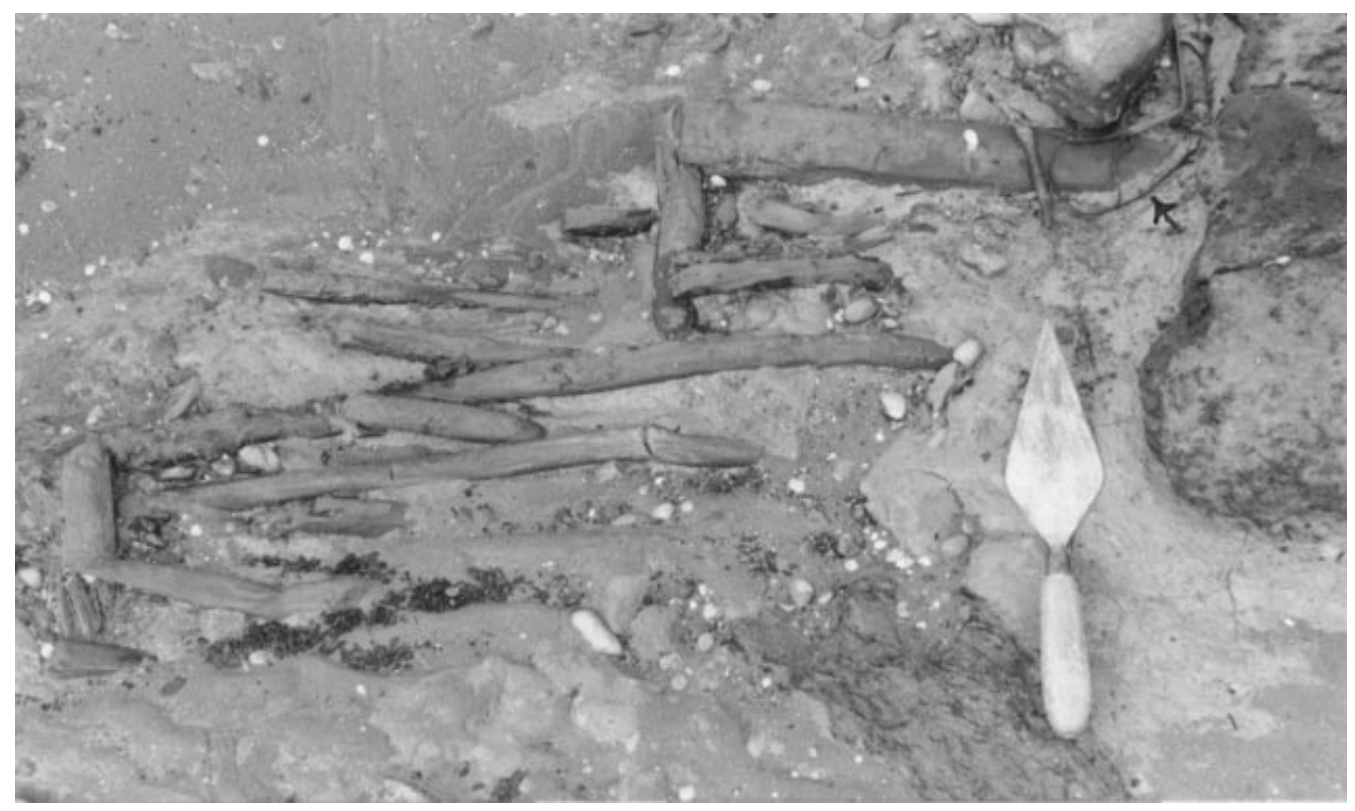

Fig. 19. Pole and hurdle with chord (arrowed), Western Palaeochannel (late phase), lower foreshore. Trowel $0.28 \mathrm{~m}$ long for scale

channel between Magor Pill and the sewer outfall is a fragment from a hazel hurdle to which a length of cord had been tied. A larger fragment from a woven panel of hazel, again with a short piece of cord, occurs among rounded lumps of peat and silt in the fill seen on the lower foreshore (fig. I9). The panel consists of a straight stake or pole c. $80 \mathrm{~mm}$ wide and $0.8 \mathrm{~m}$ long into which lengths of hazel c. $35 \mathrm{~mm}$ diameter had been slotted at intervals of $c .0 .4 \mathrm{~m}$. Loosely woven between these laterals are lengths of roundwood $20-25 \mathrm{~mm}$ in diameter. The pole gave a conventional radiocarbon age of $220 \pm 50$ years BP. ${ }^{44}$ Further out on the lower foreshore is a more substantial portion, measuring $c$. 0.8 by $\mathrm{Im}$, from a woven panel of hazel (fig. 20). Between sails $25-30 \mathrm{~mm}$ in diameter spaced c. $0.3 \mathrm{~m}$ apart are loosely woven laterals measuring $15-25 \mathrm{~mm}$ across. All three fragments lay almost horizontally in the sediment, suggesting that the panels had not been erected where buried.

We identified six fishing baskets of a more delicate construction (e.g. fig. 2I) preserved at various points in the lower layers of the fill (fig. 2b). The example in figure $2 \mathrm{I}$ is a tapering structure composed of willow withies a few millimetres across that lie closely woven between stouter, longitudinal shoots. All the baskets appear to be fragmentary and most lay among peat blocks on the margins of the palaeochannel; none came with possible fixing stakes. Exposed in oblique to longitudinal section, one was a conical basket attached within another of barrel-shaped form.

Pottery sherds of a number of periods are very thinly but widely stratified in the late phase deposits (fig. 2b). Locations on the upper and lower foreshores gave RomanoBritish wares in the form of slightly to moderately abraded body sherds from South-East Dorset BBI (two sherds) and a variety of grey-ware vessels (three). We recorded medieval (eleventh-sixteenth century) ceramics from eight find spots ranging from east 


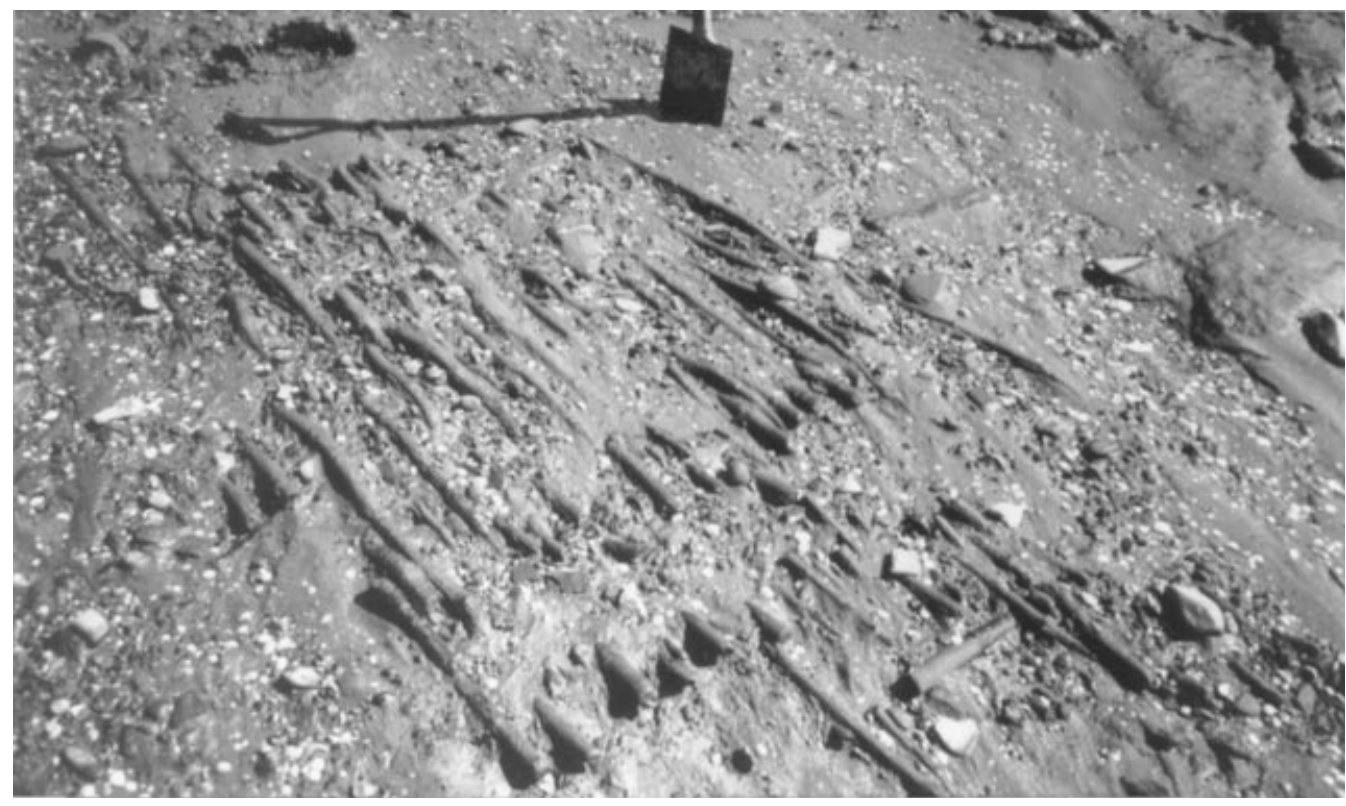

Fig. 20. Part of hazel hurdle, Western Palaeochannel (late phase), lower foreshore. Spade $0.14 \mathrm{~m}$ wide for scale

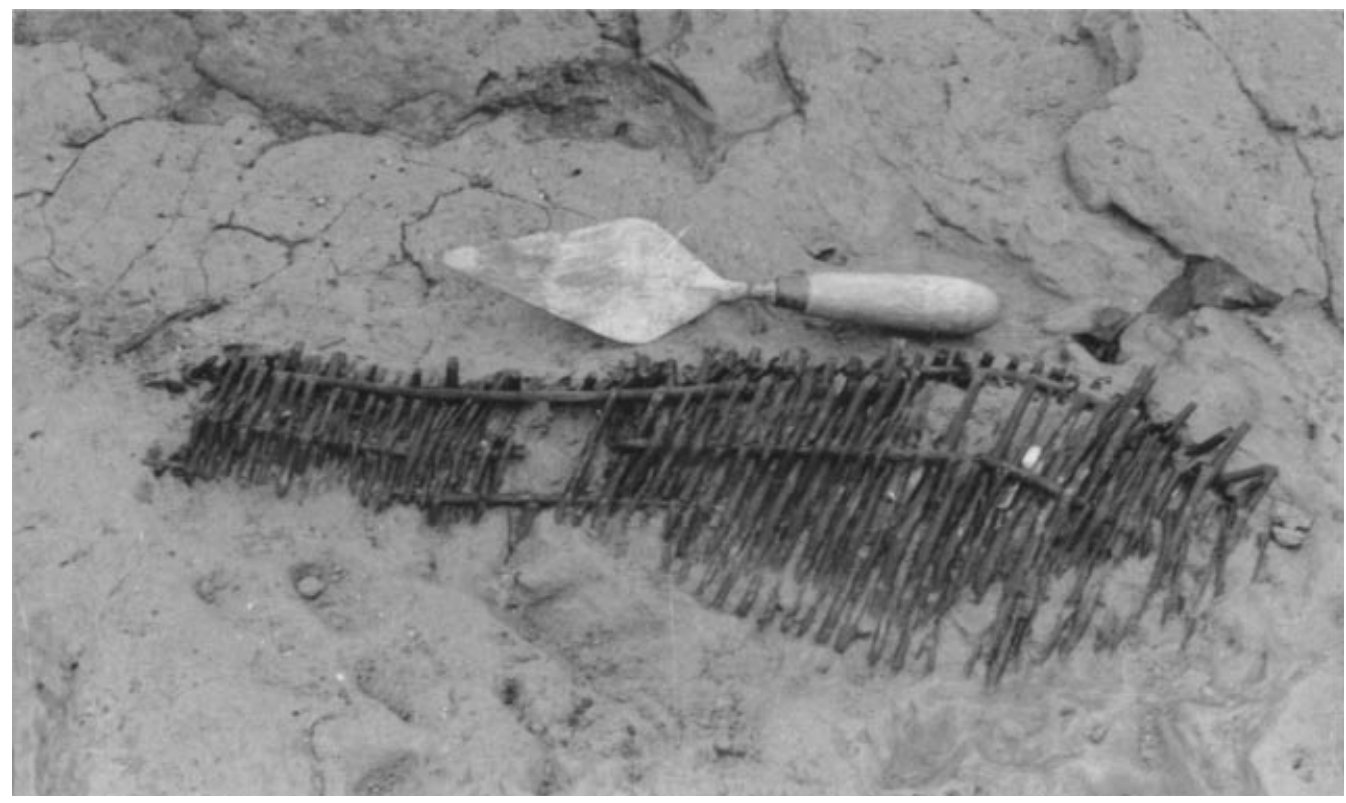

Fig. 2 I. Fragment of finely woven fishing basket, Western Palaeochannel (late phase), outer edge of upper foreshore. Trowel $0.28 \mathrm{~m}$ long for scale 
of the sewer outfall to $125 \mathrm{~m}$ out on the lower foreshore. The pottery (nine sherds), with an emphasis on the eleventh-thirteenth century, varies from pristine to slightly abraded sherds from cooking pots and jugs/pitchers, and includes 'Bristol Wares' of the early eleventh to late twelfth century and Penhow Castle Ware of the late twelfth to thirteenth century, together with unprovenanced items. One of the latter is a body sherd from a jug/pitcher in a hard, brownish yellow fabric, with very abundant inclusions of well sorted and rounded, occasionally rose-coloured, medium quartz sand; there are internal and external patches of a strong green glaze. The whole is reminiscent of early medieval Brill/Boarstall Type Wares (fabric OXAWI) from the Oxfordshire-Northamptonshire border. ${ }^{45}$ We also recovered substantial fragments from two, medieval, glazed ridge tiles, one in early Malvern Chase fabric.

A mixed assemblage of abraded medieval and early modern artefacts occurred at a find spot near the boundary between the upper and lower foreshores. Body sherds from a Stroat Ware (late sixteenth-seventeenth century) bowl and a Ham Green Ware (thirteenth century) cooking pot were accompanied by a large piece from the edge of a spun disc of window glass.

Five locations yielded chiefly early modern artefacts. From basal beds within a few metres of early medieval finds east of the sewer outfall came a fragment from the stem of a clay tobacco pipe. At a spot further west, we found the abraded, broken bowl with piece of stem attached of an unstamped clay tobacco pipe of the late seventeenth/?earliest eighteenth century. The finds at other spots include pieces of bluish grey roofing slate, and slightly abraded body sherds (two) from Stroat Ware (late sixteenth-seventeenth century) bowls and a Surrey/Hampshire Border Ware pitcher/flagon (mid-sixteenth to eighteenth century). From what on stratigraphical grounds could be the youngest part of the fill came an enigmatic find, a body sherd from a large, cylindrical vessel of hard, unglazed porcelain, apparently thrown in a mould and then turned externally. It recalls porous pots from nineteenth-century wet electrical cells.

Most of these sherds have rounded edges and corners and damaged glaze (if present), and have clearly suffered water transport. Two large sherds, however, are pristine, with sharp corners and edges; only these could with any certainty be either direct discards into the palaeochannel or have been displaced downward in sediment slumps.

Perhaps the most remarkable find, by N. Nayling (Glamorgan Gwent Archaeological Trust), S.J. Rippon, R.C. Turner (Cadw) and D. Upton (Caldicot) after post-survey cleaning of the foreshore by favourable winds, is the forward part of a wooden boat (fig. 2b), as excavated and described by Nayling. ${ }^{46}$ This wreck dates dendrochrono-logically to the mid-thirteenth century. Clinker-built and of 'keel' type, with planks held by iron rivets, the vessel had a beam of $2.5 \mathrm{~m}$ and an original length of $15 \mathrm{~m}$, of which $7 \mathrm{~m}$ including the bow remained. Prior to excavation, only about $4.5 \mathrm{~m}$ of riveted planking and ribs were visible on the foreshore. The boat lay almost upright in pale brown silts with some gravel near the north-eastern edge of the palaeochannel, and was infilled by c. Im of layered silts, gravel, and lumps of peat and silt derived from the Wentlooge Formation. The surviving cargo (c. I 70kg) was of iron ore, supported on a weightspreading hurdle. We examined a random sample (I2.I kg, 57 pieces) of the ore, finding chiefly massive to banded goethite in lumps up to $c .2 \mathrm{~kg}$ in weight, with some haematite and, as gangue, well-crystallized quartz, calcite, and a little dolomite. The cavities in many lumps were lined with manganese oxides, varying in thickness from a mere film to a soft, millimetre-scale layer. Some of the goethite occurred as yellow-brown ochre. 
Table I. Numbers of transposed Iron Age, Romano-British, medieval and early modern pottery sherds and other ceramic items from the lower foreshore at Magor Pill

IRON AGE

Calcite-tempered Ware (by M.G. Fulford)

ROMANO-BRITISH (by M.G. Fulford)

Samian

Central and South Gaulish (late first-second century)

Severn Valley Ware

jars and tankards (second-third century)

Oxfordshire Ware

white-ware mortarium (late third-fourth century) and red colour-coats

Miscellaneous Oxidized Sandy Wares

South-east Dorset BB I

everted-rim jars, cooking pots, bowls and dishes (second-fourth century, but emphasis on third and fourth century)

Miscellaneous Black Wares

everted-rim and straight-sided jars, and bowls (third-fourth century)

Micaceous Grey Ware (Gloucester $\mathrm{TF}_{5}$ )

jars and bowls (late third-fourth century)

Miscellaneous Grey Wares

cooking pots, bead-rim jar, everted-rim jars (late first-fourth century)

?Savernake Ware

Sub-total

$3 \quad(3.0 \%)$

$5 \quad(5.0 \%)$

$3 \quad(3.0 \%)$

I $\quad(1.0 \%)$

36

$(35.6 \%)$

I5

$(14.9 \%)$

$(4.0 \%)$

30

IOI

$(29.7 \%)$

(1.0\%)

(100.2\%)

MEDIEVAL

Penhow Castle Ware

cooking pots (late twelfth-thirteenth century)

Glamorgan Ware

cooking pot (twelfth-fourteenth century)

'Bristol' Wares

cooking pots (early eleventh-late thirteenth century) and a bowl (late thirteenth century)

Ham Green Ware

cooking pot and a jug (thirteenth century)

Malvern Chase Ware

cooking pots (thirteenth century)

Miscellaneous Cooking Pot Fabrics

(eleventh-fourteenth century)

Limestone-tempered Ware

cooking pot/bowl

Micaceous Ware

?jug

Sub-tota

\section{EARLY MODERN}

Malvern Chase Pink Ware

jugs and bowls (mid sixteenth-seventeenth century)

Stroat Ware

chiefly large bowls (sixteenth-early eighteenth century)

North Devon Gravel-tempered Ware

chiefly large bowls (late seventeenth-eighteenth century)

South Somerset Ware

bowls and jars (mid sixteenth-eighteenth century)

Aston Keynes Ware

bowl (sixteenth-mid eighteenth century)

Post-medieval Welsh Borderland Ware

Miscellaneous Micaceous Ware

bowls

Sub-total

ROOF TILES

Malvern Chase

ridge tile in pink fabric

Miscellaneous fabrics

ridge and other tiles

Sub-total

$\begin{array}{cr}\text { 4 } & (8.5 \%) \\ \text { I3 } & (27.7 \%) \\ \text { I4 } & (29.8 \%) \\ \text { I I } & (23.4 \%) \\ & (2.1 \%) \\ \text { I } & (4.3 \%) \\ 2 & (4.3 \%) \\ 2 & (100.1 \%) \\ 47 & \\ & \\ & \\ \text { I } & (10 \%) \\ 9 & (90 \%) \\ \text { IO } & (\text { I00\%) } \\ \text { I94 items } & \end{array}$

Grand total 
As well as these ceramic and wooden items, the late phase yielded here and there the bones and teeth of domestic animals. An upturned cattle skull, associated with a fishing basket and abraded Romano-British and medieval sherds, was exposed on the surface within a few metres of the boat wreck; more Romano-British and medieval sherds were recovered from the silt and gravel upcast left from the excavation of the boat. Jammed among peat blocks on the outer side of the channel loop east of the sewer outfall we discovered a partly articulated cattle skeleton. From other spots we excavated the dispersed ribs and limb bones of cattle and sheep and the jaw of a sheep.

\section{MODERN MAGOR PILL}

Cutting the Wentlooge Formation and all elements of the palaeochannel complex, Magor Pill today strikes almost due south across the marshes and peat ledge before its waters spread unchannelized over the lower foreshore (fig. 2b). This almost straight course can be further traced as an irregular double row of peat blocks for $c$. Ioom beyond the peat cliff. Although thickly obscured by contemporary mud, storms occasionally show that the blocks lie in pale brown silts like those described from the Western Palaeochannel.

A seventh fishing basket lay embedded in these silts on the western side of the abandoned channel (fig. 2b). This incomplete structure is larger and of a stouter construction than the other baskets. What survives is somewhat barrel-shaped, measuring c. $0.8 \mathrm{~m}$ in length and tapering from $c .0 .7 \mathrm{~m}$ to $c .0 .3 \mathrm{~m}$, and built of longitudinal roundwood elements $c .20 \mathrm{~mm}$ in diameter between which are loosely woven lateral elements, a few some $\mathrm{I} 2 \mathrm{~mm}$ in diameter but most $2-5 \mathrm{~mm}$ across. Associated with but not directly attached to the basket was a roundwood stake $0.7 \mathrm{~m}$ long; another, pointed stake of $0.6 \mathrm{~m}$ lay nearby.

\section{SEMI-MOBILE FORESHORE GRAVELS}

Isolated sheets and patches of semi-mobile gravel erosively seal the Western Palaeochannel on the lower foreshore and lie across beds of the Wentlooge Formation (fig. 2b). They consist of rounded pebbles and cobbles, derived from local Pleistocene gravels, set tightly and firmly in a compact matrix of muddy, shelly sand, the surfaces of most patches and sheets having the appearance of a smooth, even pavement. The clasts seem to experience transport, a few at a time, only during storms or the strongest tides. Most have organically dulled or blackened surfaces, a few support juvenile barnacles, and others are holdfasts for weed. Although modern, judging by their contained metal, plastic and moulded glass items, these lag gravels are important because they trap and incorporate artefacts transposed from stratified contexts in older deposits as the foreshore continues to be eroded vertically. ${ }^{47}$

Repeated line-walking of the gravels in the mapped area afforded a small, systematic collection of pottery sherds (I 84 items) ranging from a few grams in weight, and representing a tiny fraction of a vessel, to substantial portions of several hundred grams. No sherds are without some trace of water-wear and many are also badly stained. The least affected show a barely detectable rounding of edges and corners and a still bright glaze (if present), particularly on concave surfaces, although with isolated scratches. The 
Table 2. Numbers of transposed animal bones and teeth from the lower foreshore at Magor Pill

\begin{tabular}{lccrr}
\hline animal & bones & teeth & \multicolumn{2}{c}{ combined } \\
\hline cattle & 30 & I & 44 & $(41 . \mathrm{I} \%)$ \\
horse & I & I I & 28 & $(26.2 \%)$ \\
sheep & 6 & 4 & IO & $(9.3 \%)$ \\
human & I & & I & $(0.9 \%)$ \\
others & & & 24 & $(22.4 \%)$ \\
Totals & 54 & 29 & IO7 & $(99.9 \%)$ \\
\hline
\end{tabular}

most affected have fully rounded corners and edges, with any glaze dulled, cracked or chipped, and surface clay slips/washes surviving only where sheltered (e.g. beneath rims). Some sherds lack most and a few apparently all of their glaze. Like artefacts stratified in the palaeochannel complex, the assemblage is multiperiod (table I), even ignoring the modern items in the gravels. Chiefly later Romano-British wares dominate (IOI sherds), with mortaria, cooking pots and eating bowls well represented, followed by early modern (47) and medieval (chiefly eleventh-fourteenth century) fabrics (33). We found no clear areal variation in their relative proportion and quality of preservation, although our impression was that small sherds were most frequent toward the northeast, perhaps a consequence of tidal sorting.

The bones and teeth of domestic animals (I06 items) also became trapped in the gravels and, in view of the stratified finds, we presume that these too were transposed from older contexts..$^{4}$ Cattle predominate followed by horse and sheep (table 2), and there is one human bone (femur). The animals are almost exclusively mature, with all parts, from meat joints to extremities (horn cores, skulls, small limb bones, hooves), well represented. The bones are blackened but unmineralized. Very few are broken and none showed signs of either butchery or food preparation/eating; their present context adequately explains the few with light scratches.

\section{SEABANKS AND OUTFALLS AT MAGOR PILL}

As dominant features in the archaeological landscape, the palaeochannels are challenged only by the seabank (fig. 2b), without which the settled, agricultural land-claim in the hinterland of Magor Pill could not have either come to exist or endure. The modern seabank is a majestic structure. South-west of the pill it is a trapezoidal earth bank with to seaward a tall, stone pitching, apparently mounted largely on a former inner portion of the peat ledge. A concrete wave-return wall tops the pitching. The defence to the north-east is a bank with a skirt of armour, seen from the level of the high marsh. Mill Reen has an outfall at a large, metal flap-valve seated in stonework. ${ }^{49}$

The seabank of today is almost certainly not on the same line as the first defence built in the area, and need not have reached its present position everywhere in a single stage. It appears to have been (a) set back across the land-claim defined by the primary structure and, like many others on the Severn Estuary Levels, ${ }^{50}$ was unquestionably (b) shortened along the banks of what are now Mill Reen and Pratt Reen. 


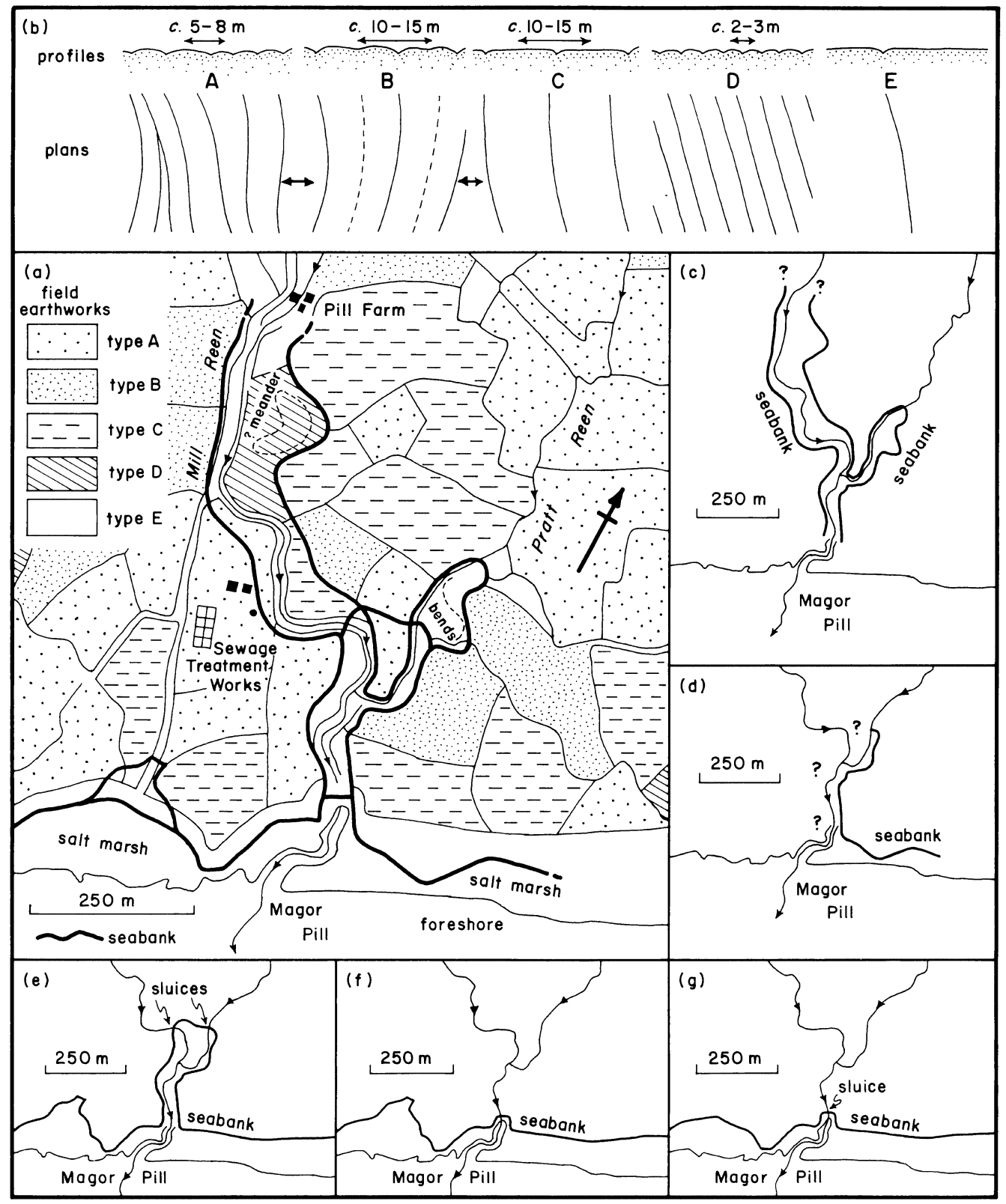

Fig. 22. Historical sea defences and outfalls at Magor Pill, (a) types of field earthwork near Magor Pill, in profile and plan, (b) positions of all sea banks recognized on documentary and field evidence, (c) earliest defences (pre-175I), (d) by I75I, (e) by I830, (f) I946, (g) I967 to present day 
Where stratigraphic and/or documentary evidence demonstrates from other parts of the Severn Estuary Levels that a seabank had been set back inland across an older agricultural landscape, ${ }^{5 \mathrm{I}}$ the repositioning of the defence created some fields that are patently atypical in size and shape.$^{52}$ Furlongs of classical ridge-and-furrow, 53 and fields defined by hedges and/or ditches, are reduced in area to as little as a hectare; the length of individual lands falls to just a few times the width or less. Typically, such deviant fields are triangular. At least fifteen fields on the Caldicot Level ${ }^{54}$ appear to have been modified in these ways (e.g. ST 346824, 358825, 377823, 394828, 417835, 431843, 475869, 482873). One example lies just 45om north-east of Magor Pill (fig. 22a).

Both field and documentary evidence point to the seaward migration of outfalls as seabanks were shortened along the reens. For a period prior to the mid-eighteenth century, the defence ranged a short way inland along the banks of the modest Pratt Reen and far inland along the much larger Mill Reen, probably at least to Pill Farm (fig. 22a, c). This seabank is evident in early air photographs ${ }^{55}$ as either a cropmark or earthwork (fig. 23), and locally remains visible as the latter. Either conforming to it or post-dating it are at least three, intergrading kinds of field earthwork in the pastures (fig. 22b): type A, indistinguishable from classical ridge-and-furrow, ${ }^{56}$ but not necessarily with the same significance as in midland England; 57 type B, like type A but with a slight axial depression; and type C, with furrows or definite 'grips' separating wide, level areas. Other fields reveal either narrow, geometrical ridges (type D), locally called 'ridge-andvurrow', or are smooth except for the occasional grip (type E). Tidal silts would have been deposited along Mill Reen at least as far as Pill Farm during this early period.

By I75I, however, the outfall and defence on Pratt Reen had been moved downstream, ${ }^{58}$ where there survives a modest structure of mortared, roughly dressed Old Red Sandstone and Lias limestone, largely obscured by modern concrete additions (figs 22a, d, 23). This simplification on Pratt Reen was presumably part of a larger development also involving Mill Reen, for by 1830 , and possibly by 1756,59 the seabank ranged across both reens, ${ }^{60}$ defining a P-shaped area of salt marsh (figs 22a, e, 23). The position of the outfall on Mill Reen can be identified today only where roughly dressed blocks of Old Red Sandstone (Brownstones) lie tossed into the hedgerows. A small field where the reens join was abandoned when a straight defence, surviving as a degraded bank and ditch, was built $c$. I $50 \mathrm{~m}$ inland. A more substantial set back had occurred by I 830 to the east of Magor Pill, ${ }^{6}{ }^{6}$ where a straightened defence truncates largely type $\mathrm{C}$ ridges (fig. 23). By $1946^{62}$ the separate outfalls on Pratt Reen and Mill Reen had been replaced by a single, little recessed sluice where the contemporary one stands (figs 22a, f, 23). The last alteration, in 1967 (pers. comm. C. Green, I994), was the closure of a re-entrant in the bank 250m south-west of Magor Pill (figs 22a, g, 23), resulting in the fields being expanded to include visibly more elevated areas of high marsh. ${ }^{63}$

\section{DISCUSSION}

\section{Coastal change}

Retreat is the dominant, recurrent theme in the behaviour of the coast of the Severn Estuary Levels over the last few millennia, the pattern of intertidal erosion depending to a significant degree on the greater resistance of the peats than the silts in the Wentlooge 


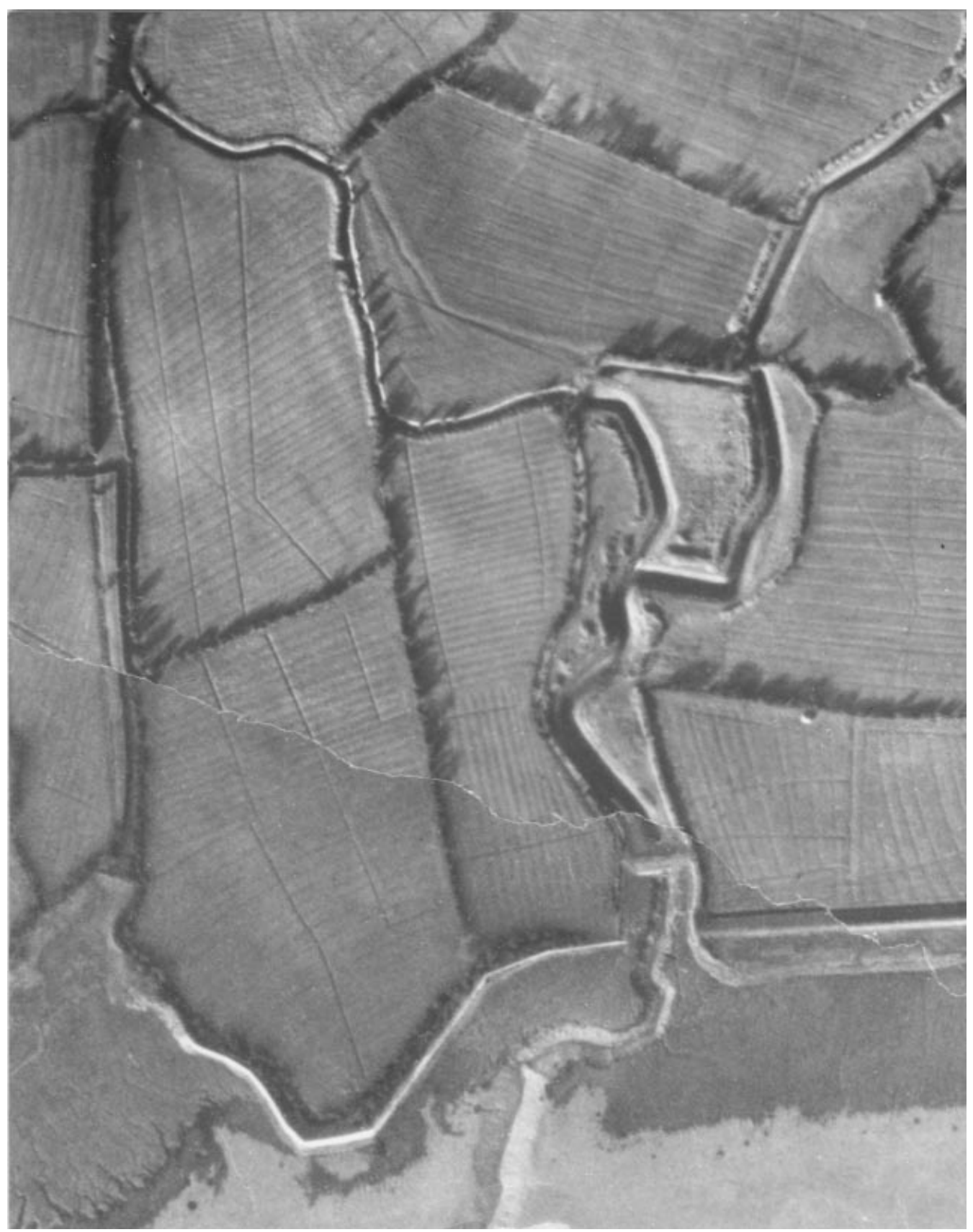

Fig. 23. Air photograph (c. $500 \times 650 \mathrm{~m})$ of the Magor Pill area in 1946 . North to upper right. Photograph: Royal Airforce Air Force. Crown Copyright Reserved 
Formation (figs Ic, 3). On a shore unconstrained by defensive works, erosion creates a bold marsh cliff in the upper silts that overlooks a broad peat ledge, or group of ledges, which caps the more resistant middle Wentlooge beds. To seaward, that ledge is itself bounded by a cliff, overlooking a broad foreshore cut in the lower Wentlooge silts. The peat cliff, however, retreats more slowly than the marsh cliff at the level of high tides, when the water is deepest, the water level changes least rapidly, and wave action is most effective. The deep desiccation of the marsh silts at times of weak tides also facilitates their erosion. ${ }^{64}$ In their prehistoric state, the marshes that bounded Magor Pill reached to coasts much nearer the axis of the estuary than the most seaward part of the modern seabank. We cannot say precisely where these shorelines lay, but each set of geological and/or archaeological features, in most instances chronologically distinctive, suggests a limiting position.

Consider the evidence afforded by the distribution of peat blocks and the surviving stratified peat. The presence far out on the lower foreshore of blocks of a peat terminated at about 2430 radiocarbon years BP that survived the collapse with other beds into a channel (figs $2 \mathrm{~b}, 3$ ) suggests that, by the early the Iron Age, the coast was not less than $525 \mathrm{~m}$ further seaward (fig. 24a). Other evidence (see below) would place the coast much further seaward. By the latest Iron Age, however, the marsh cliff was not less than I $70 \mathrm{~m}$ further out (fig. 24b), since the Eastern Palaeochannel yields occupation debris of this date ${ }^{65}$ almost where it cuts the modern peat cliff (fig. 2 b). Again, this position for the coast represents an absolute inland limit for the final Iron Age. A rate of coastal retreat of not less than about $0.7 \mathrm{~m} /$ year is implied.

Next consider the textural properties of the palaeochannel fills (fig. I2). On these grounds, the final Romano-British coast could have been positioned not less than about $800 \mathrm{~m}$ away from the modern seabank (fig. 24c); the Iron Age shore and the feather edge of the peat could have been still further out. We note that the early-phase deposits filling the Western Palaeochannel at the bedrock ridge (fig. 2b) smoothly continue the trends in coarseness and grain-size patterns detected further inland (fig. I2a, c), making it unlikely that the two outcrops represent different systems. We also point to the fact that the fill at the ridge is relatively coarse, suggesting proximity to the channel mouth; the oldest dated parts of the fill, exposed high on the upper foreshore (fig. 2b), are attributed to earliest post-Roman times. Where the wreck of the thirteenth-century boat became buried in the Western Palaeochannel, the late phase silts are similar in coarseness to those of the early fill at the ridge $c$. $450 \mathrm{~m}$ further seaward (figs $2 \mathrm{~b}, \mathrm{I} 2 \mathrm{c}, \mathrm{d}$ ). Hence the marsh cliff at this stage in the medieval period could have stood not less than $350 \mathrm{~m}$ off the modern seabank (fig. 24d). The boat may have been wrecked (or deliberately beached) in the then mouth of Magor Pill. That mouth would seem to have retreated inland from its Romano-British position, but it is unlikely to have been situated further seaward than the stake setting on the bedrock ridge (figs $2 \mathrm{~b}, 24 \mathrm{e}$ ), dated to the late tenth century (see above). This setting lies along and not across the axis of the palaeochannel. Consequently, it is strongly reminiscent of the rows of posts used as anchorage for the fishing baskets called putts that are laid out across the tidal streams on level, open shores. ${ }^{66}$ In the Severn Estuary, post settings for putts, and the related frames for putchers, typically are to be found just off a marsh cliff or peat ledge, to which they are commonly anchored, as can be seen to the north-east of Magor Pill and elsewhere.

We can go on to form estimates of the rates of coastal retreat, assuming that the marsh cliff had been forced back to approximately the line of the defence by $c$. AD I600, 


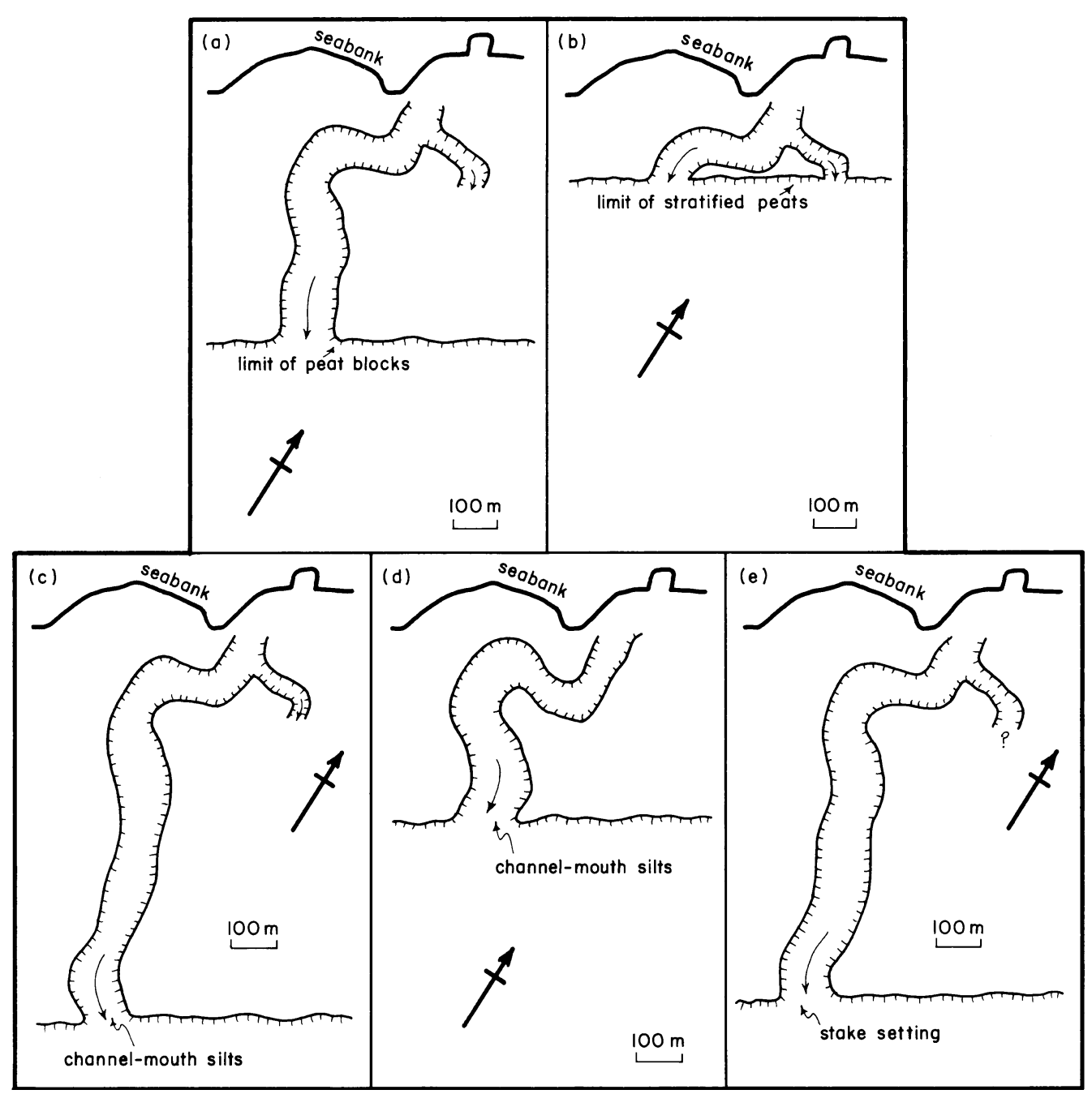

Fig. 24. Possible positions of the coast at Magor Pill, (a) Maximum inland position in the early Iron Age, (b) Maximum inland position in the final Iron Age, (c) Earliest post-Roman times, (d) The mid thirteenth century, (e) Maximum seaward position in the mid-tenth century

as seems reasonable from the evidence for the date of set-back (see below). The average rate since Roman times appears to have been $c .0 .68 \mathrm{~m} /$ year. The position of the boat wreck suggests a later acceleration to an average of $c .0 .83 \mathrm{~m} / \mathrm{year}$. These estimates based on the textural evidence do not seem unreasonable, since the bold marsh cliff on Rumney Great Wharf on the Gwent coast to the south-west of Magor Pill is currently retreating at $c$. Im/year. Moreover, the similarity between the two rates estimated on textural grounds strengthens our less conservative conclusion regarding the position of the Iron Age to Roman coast. On the basis of the stake setting and boat, however, an average 
retreat rate of $1.5 \mathrm{Im} /$ year is obtained for the period from the late tenth to the midthirteenth century.

How were the Western and Eastern Palaeochannels related in the early landscape? Since the channel fills abound in peat blocks, and the peats themselves lack any detectable lateral facies changes suggesting contemporaneity with the channels, we conclude that the latter were initiated and cut in harmony with the building of the overlying and essentially transgressive minerogenic marsh deposits. ${ }^{67}$ Possibly the early drainage from the developing marsh followed the Eastern Palaeochannel, in view of the late Iron Age occupation debris in its fill. The fill of the Western Palaeochannel apparently is largely younger, on the basis of radiocarbon-dated wood from earliest postRoman times onward and the widely dispersed, medieval to early modern finds. For a time, however, the two channels could both have been active. There is no significant difference in coarseness and grain-size patterns between the fills closest in age over the same interval of downstream distance (fig. I2a-c). The origin of the Western Palaeochannel is unknown, but possibly it was initiated when a headward-eroding tidal creek captured the eastern drainage. ${ }^{68}$

A significant change of regime affected the Western Palaeochannel as it slowly grew in sinuosity. The late phase, with its medieval to early modern artefacts, differs sharply in colour from the early phase, and is widely related erosively to those deposits (fig. 2b). Moreover, although alike in coarseness and in texture-distance trend, the two phases present dissimilar grain-size patterns (fig. I2a, c, d). We tentatively suggest an abrupt change to a regime of greater hydraulic duty or different salinity, broadly in about the eleventh century from the dating evidence, although whether of human or natural cause is unknown. A similar pale brown fill in the Caldicot Level is known only from the abandoned channel deposits of Collister Pill (ST 454855), where there is also a drainage outfall.

\section{Settlement and trade at Magor Pill}

By the mid-eighteenth century, the seabank was essentially on its present line. ${ }^{69}$ There is scant evidence, however, for the age of the primary defence, but Roman land-claim is not out of the question, in view of scattered finds from the hinterland ${ }^{70}$ and the intertidal zone. ${ }^{71}$ Boon's Romano-British pottery from the Sewage Treatment Works, landward of the earliest seabank (fig. 22a, c), hints at Roman enclosure, but the low altitude (c. 3.6m OD) of the finds is as compatible with dumping in a creek as in a field ditch. The occupation debris reported by Barnett came from an even deeper level. Perhaps the most compelling evidence for Roman embanking ${ }^{72}$ is the Goldcliff Stone, ${ }^{73}$ commemorating the building by legionaries of some major structure, possibly a seabank and/or drain. ${ }^{74} \mathrm{It}$ may also be chronologically significant that, north of the Sewage Treatment Works, a long stretch of the earliest defence is overlain by type A earthworks (fig. 22a), indistinguishable from classical ridge-and-furrow. The fact that the enclosed land at Magor Pill is only $0.6 \mathrm{~m}$ less in altitude than the neighbouring high marsh (fig. 3) is not evidence against Roman land-claim, ${ }^{75}$ since at Goldcliff $7 \mathrm{~km}$ to the south-west there was a chiefly later Romano-British rural settlement on or near the bedrock 'island' but, on the adjoining alluvium on which fields had been laid out, apparently substantial postRoman tidal flooding. ${ }^{76} \mathrm{~A}$ definite terminus ante quem for the primary defence is provided by the grant to Tintern Abbey (founded II3I) by c. II50 of the Lower Grange, just 
I. $5 \mathrm{~km}$ across the alluvium to the north-west of Magor Pill. ${ }^{77}$ Hence the change in regime of the Western Palaeochannel suggested by its textural features (fig. I2c, d) is less likely to record primary enclosure than the revitalization and reorganization of a longestablished but decayed system of defence and drainage, or even the continued widening of the estuary. ${ }^{78}$

The repositioning the seabank is perhaps easier to date. On the nearby Wentlooge Level (fig. Ib), a Romano-British defence was set back over a $\mathrm{I} 2 \mathrm{~km}$ frontage in late medieval times. ${ }^{79}$ Extensive repositioning in the earliest seventeenth century can be demonstrated from higher in the estuary. ${ }^{80}$ Hence a late medieval set-back at Magor Pill seems most plausible.

The course of modern Magor Pill (fig. 2b), established by $1830,{ }^{81}$ is straight and, therefore, artificial looking. An act of straightening, denying the Western Palaeochannel fresh water, and so promoting its siltation, may have been necessary to protect the repositioned defence south-west of the sewer outfall, where the old channel loops back dangerously close toward an embayed length of seabank (fig. 2b). This was certainly the cause of the recent realignment of Goldcliff Pill. ${ }^{82}$ As noted above, the seemingly artificial cut at Magor Pill extended $c$. Ioom further seaward of the peat cliff seen today. The corresponding and almost identical feature at Goldcliff is retreating at $c .0 .25 \mathrm{~m} /$ year. ${ }^{83}$ At that rate, Magor Pill was straightened $c$. I600. That the silts exposed along Mill Reen are as coarse as those which fill the Western Palaeochannel (late phase) a kilometre away on the peat ledge (figs I Ib, I2d) is compatible with the straightening and the continued retreat of the coast. This would place the first reorganization of seabanks along Mill and Pratt Reens between c. I600 and I75I (fig. 22d).

Despite the meagre evidence for the age of the primary defence, we have little doubt that there was an important Romano-British settlement on enclosed land at Magor Pill. Now largely if not wholly lost to the sea, it had become established by the second century, and flourished in the later Roman period. Our pottery assemblage obtained by controlled sampling is relatively small (table I), but considerable, unsystematic collections similar in general character have also been made intertidally. ${ }^{84}$ Vessels for food storage, preparation, cooking, and eating and drinking are well represented in all assemblages, and South-East Dorset BBI, associated with other south-western products, far outweighs any other single ware. Given the very low ratio of BBI at Cornish Romano-British sites, Magor Pill in Roman times, like the rural settlements at Goldcliff $^{85}$ and the Wentlooge Level, ${ }^{86}$ could have been linked by sea with ports on the Avon-Somerset coast, only $c$. Iookm by road from the kilns at Poole Harbour. ${ }^{87}$

Magor Pill affords evidence in the historical period of two activities - tidal powergeneration and sea trade - inevitably tied to the coast. A settlement there, or at least a collection of buildings, is variously called 'Aberweythel', 'Abergwaitha' or 'Aberwathel' (meaning, works at the mouth of the river) ${ }^{88}$ Like the Romano-British settlement, it is probably now lost to the sea. The first known record of Abergwaitha is from 1245, when the keeper and tenants of a mill there assumed responsibility for a watercourse running 'per median alban waldan' (meaning, through the middle of the white wall). ${ }^{89}$ The 'alban waldan' can be interpreted as not the present Whitewall Reen, but the embanked and raised Mill Reen a little to the east, which even today discharges into Magor Pill. A port at Aberweythel was in 1327 described as 'wholly deserted'.90 A mill at Abergwaitha is again cited in 1469, and clearly to the east of Whitewall Reen. ${ }^{91}$ Dr Thomas Phaer described Magor in the mid-sixteenth century as 'a pill or creke' from which assorted 
agricultural produce and victuals were carried to ships; the trade from nearby Goldcliff was stated to be with Bristol..$^{22}$

Until the wreck is better known, we cannot fully place the boat in the scheme of medieval activities. However, as there is as yet no evidence for medieval iron-making in the Magor area, and the Forest of Dean, Bristol-Mendip area, and South-east Crop of the South Wales Coalfield are the chief regional sources of widely sought rich ores, the vessel may have foundered in Magor Pill after a storm rather than traded there, although a link to the Cistercians of Tintern cannot be excluded, as the monks from early on plied boats across the Bristol Channel and smelted iron..$^{93}$ The observed assemblage of ore and gangue minerals rules out the Forest of Dean as the source, where quartz gangue is almost unknown, ${ }^{94}$ but suggests an origin in either south-east Wales ${ }^{95}$ or the Bristol-Mendip area..$^{96}$ The balance of evidence favours the latter source, given that manganese oxides contribute noticeably to the ores from the wreck. The mouth of the pill was the final resting place of the vessel, judging from the grain-size evidence (fig. I2c, d).

From the sixteenth to the eighteenth century in particular, there was a vigorous sea trade in store cattle from many ports large and small on the Gwent coast across the Bristol Channel to south-west England. ${ }^{97}$ Abergwaitha, or rather a pill carrying that name, was again a landmark in the mid-seventeenth century, ${ }^{98}$ but was perhaps by then just an embarkation point on Magor Pill, as eighteenth-century maps show neither buildings nor structures there. ${ }^{99}$ The site of Abergwaitha should not be confused with modern Cold Harbour Pill, ${ }^{100} \mathrm{Ikm}$ south-west of Magor Pill. In the mid-eighteenth century, Cold Harbour Pill was a branch of Magor Pill. ${ }^{\text {OII }}$ The present outfall (fig. Id), and the transfer of name with it, merely reflect later drainage reorganization.

Our finds complement this documentary evidence, suggesting that Abergwaitha waxed economically in two phases; it is surely no coincidence that the intervening lull seems to cover the period - the cool and stormy 'Little Ice Age' ${ }^{\text {IO2 }}-$ when natural changes forced set-back of the sea wall. Although modest in size, and dominated by material removed from subaqueous and terrestrial primary contexts, there is a clear emphasis in our stratified and transposed pottery collections (table I) on a range of mainly imported, medieval wares ranging from the eleventh up to the fourteenth century, when Abergwaitha was described as a deserted port. Courtney's two cooking pots and a jar from the Magor foreshore seem also to be imported products of this general date. ${ }^{\mathrm{I} 3}$ The main post-Roman emphasis, however, is on sixteenth century and early modern wares. Excepting the Miscellaneous Micaceous Ware, which could be local, and based on early Old Red Sandstone deposits, ${ }^{104}$ the assemblage is of imported vessels from west and south-west England and the nearer, more accessible Midlands. Some wares even came from the European mainland. ${ }^{\text {Ios }}$ Confirming the documented links by sea with the southern shores of the Bristol Channel, the high ratios of incoming Devon and Somerset wares fit well with the substantial, outgoing trade in livestock reported from the sixteenth to eighteenth century. ${ }^{106}$ At this time, large numbers of cattle, horses and sheep were being shipped from Wales for fattening on the rich Somerset and Devon pastures. The bones and teeth from the late phase of the Western Palaeochannel, and particularly the large amounts trapped on the foreshore (table 2), are direct evidence for this trade, and could represent mortalities among waiting herds. 
Neither the form of Abergwaitha in medieval and early modern times is known, nor can we say whether the expected port facilities stood wholly on the marsh or partly behind a seabank. We encountered no wooden or stone structures, but the presence in the Western Palaeochannel of stone blocks, ceramic roof tiles, and window glass possibly suggests buildings, perhaps warehousing or a hamlet that served both mill and landing place.

\section{Fishing on the Gwent coast}

Many of our finds prove that fishing was an historically important activity in the vicinity of Magor Pill, as was true in the Severn Estuary and inner Bristol Channel generally, the archaeological record beginning in the seventh century. ${ }^{107}$ The two double rows of roundwood stakes (fig. 2b) could be frames supporting tiers of conical baskets known as putcher ranks ${ }^{108}$ and, from the location of one of them near to the upper foreshore, as well as from Green's review, ${ }^{109}$ may date from modern times. Alternatively, each marks the site of a putt or putch weir, ${ }^{\text {IIO }}$ a single row of comparatively large baskets secured directly against the ground. There is perhaps little doubt that this interpretation applies to the setting of split-oak stakes dating from the tenth century at the bedrock ridge (fig. 2b). A probable putt of this date is known from Sudbrook Point to the north-east, and there are contemporary documentary references to fishing apparently with these baskets. ${ }^{\text {II I }}$ The large, coarsely woven but incomplete basket from the channel of modern Magor Pill (fig. 2b) closely resembles the leading parts of modern putts. Some of our smaller, more finely woven basket fragments (fig. 2I) from the Western Palaeochannel are like the trailing ends of putts. Given the associated artefacts, they are most likely to be medieval or early modern in age. The fact that most are lodged among peat rafts on the margins of the channel suggests that they were washed in during storms after outlying settings had been damaged. The single 'basket within a basket' to which we refer may be an eel pot.

The three hurdle-like structures (figs $2 \mathrm{~b}, 19,20$ ) suggest the local use of fishing hedges to channel a catch into putts or other traps, ${ }^{\mathrm{II} 2}$ as identified from about the time of the Norman Conquest at Sudbrook Point. ${ }^{113}$ However, as no pointed sails or stakes were found, and livestock was exported from Magor Pill, we do not exclude their use for penning animals on either land or ship.

\section{THE WIDER PERSPECTIVE}

The evidence at Magor Pill demonstrates especially clearly the importance in the Severn Estuary Levels of active tidal channels as a major and enduring focus of human activity, especially if a freshwater discharge was also present. The Bronze Age occupation at Rhumney Great Wharf on the Wentlooge Level (fig. Ib) lay beside a substantial, active creek. ${ }^{\text {II }}$ Tidal palaeochannels excavated at Caldicot Pill (fig. Ib) gave evidence for a landing place and sewn plank boat of this date. ${ }^{\text {II }} \mathrm{A}$ tidal palaeochannel excavated at Barland's Farm in the same general area yielded an impressive Roman boat, ${ }^{116}$ although there is as yet no evidence for an associated settlement. ${ }^{117}$ In Somerset, there is a similarly strong association between Roman occupation on the levels and tidal rivers. Between Huntspill and Burnham-on-Sea, a series of salt production sites cluster along 
the banks of a major creek. ${ }^{118}$ Not far to the south, at Crandon Bridge on the River Parrett, there apparently stood a flourishing Roman port from which Dorset pottery carried by road was widely shipped. ${ }^{\mathrm{II}}$ To the north, the Wemberham villa ${ }^{\mathrm{I2O}}$ and a local grey-ware manufactory (Congresbury Ware) lie beside the formerly tidal Congresbury Yeo. ${ }^{\text {I2I }}$

In the middle Severn Estuary, at Oldbury Flats (fig. Ib), a Roman settlement (c. 20ha) clustered along the banks of an active tidal channel that has since disappeared as a landscape feature. ${ }^{\mathrm{I} 22}$ Sea defences apparently were built here in Roman times, but these had been set back by the early seventeenth century, leaving part of the by then silted-up Roman channel and field system exposed on the foreshore. Similar events unfolded at Hills Flats nearby. ${ }^{\mathrm{I} 3}$ The channel remained active into medieval times, when a simple stone landing place, receiving imports of high grade iron ore and recently discovered coal, was built. Across the estuary at Woolaston, in an alluvium-filled valley, the remains of a more elaborate, stone and timber quay of medieval date lies out on the foreshore beside a tidal stream. ${ }^{\mathrm{I} 4} \mathrm{~A}$ similar context, on the extended path of the Colhuw River, is described by Davies and Williams for medieval harbour-works exposed intertidally below Llantwit Major (fig. Ib). ${ }^{\mathrm{I} 25}$ These examples suggest that prospection for tidal channels and their contents could be fruitful in other British coastal wetlands, especially where boats are known, as on Humberside. ${ }^{\text {I26 }}$

Our work at Magor Pill draws attention to the importance of seabanks and outfall works as critical monuments, not only on the Severn Estuary Levels but also in wetland historic landscapes generally. ${ }^{127}$ Not only was the defence at Magor Pill set back substantially because of coastal erosion, as witnessed by the truncated fields and the Roman and later artefacts transposed into the intertidal zone, but the seabanks along Pratt Reen and Mill Reen were significantly shortened from the landward end. The staged, coastward movement of the outfalls arguably has both an economic and technological drive. As relative sea level rises, the flood defences that protect fossilized marshes must be raised ever higher and wider to remain effective, and so they become increasingly expensive to maintain. By shortening a seabank, as is possible along a creek, the maintenance cost and incidence of breaching are both reduced. The development of new building materials and powered machinery has meant that bridging outfalls can be built progressively further down tidal channels that widen and deepen seaward. It is exactly for these reasons that, following the 1953 storm surge in the southern North Sea, a dramatic shortening of the British defences was achieved by moving sluices further seaward along the fleets. ${ }^{28}$ At Magor Pill this process had begun by the mid-eighteenth century.

In our work at Magor Pill, we used an understanding of coastal processes and an eclectic range of evidence - geological, geomorphological, sedimentological, artefactual and documentary - in an attempt to reconstruct the character of enduring and wide ranging, trans-zonal human activities on a tidal stream where coastal erosion has destroyed primary archaeological contexts and landscapes. To have restricted ourselves to the intertidal area would have been as limiting as having confined the investigation to the surviving hinterland. Natural tidal siltation, particularly when the trend of relative sea level is upward, quickly conceals evidence of occupation; neglect of man-made sea defences has the same effect, as land-claims revert to salt marsh. However, while lamenting the loss of evidence due to long-standing coastal retreat and its consequences, the depth of stratigraphy which came to be exposed intertidally gave us an invaluable 
window of understanding about the evolution of Magor Pill over the last few millennia and the impact of change on the communities which depended on it. The chief remaining uncertainties must be the Roman date for primary land-claim, and the question of an early post-Roman collapse of sea defences prior to resettlement early in the present millennium.

\section{ACKNOWLEDGEMENTS}

We are most grateful to Cadw for part-funding this project and to Rick Turner for his support and encouragement. Bob Trett (Newport Museum and Art Gallery), Rick Turner (Cadw) and Derek Upton (Caldicot) generously gave in the field of their time and experience. We are grateful to Michael Fulford (University of Reading) for determining the Romano-British pottery, Colin Green (Environment Agency) for information about modern changes to seabanks, Nigel Nayling (GGAT) for an advance description of the medieval boat, and David Thornley (University of Reading) for grainsize analyses. We are indebted to Nigel Nayling for a discussion on eel pots.

\section{SUMMARY}

A geological and geomorphological survey, combined with sedimentological results, has provided a detailed, trans-zonal famework in which to examine the significance of an eclectic variety of artefactual and documentary evidence relating to prolonged human activity on the tidal stream known as Magor Pill.

The shoreline, underlain by estuarine silts and peats of the Flandrian Wentlooge Formation, has retreated by a minimum of some 8oom since Iron Age-Roman times, leaving exposed on the modern foreshore the earlier but silted-up courses of Magor Pill. As the coast retreated, fishing stakes, one a double row from the tenth century, were set up on the widening lower foreshore. The palaeochannel deposits yielded small amounts of stratified Iron Age, Romano-British, medieval and early modern occupation debris, together with woven baskets and hurdles related to the early modern and probably also medieval fishing activities in the area. One of the palaeochannels contained the wreck of a medieval, clinker-built boat carrying high-grade iron ores. By far the largest amounts of occupation debris, however, were transposed and mixed into semi-mobile foreshore gravels. This material demonstrates that there was a thriving Romano-British settlement at Magor Pill, apparently in sea connection with the southern shores of the Bristol Channel. From the eleventh to the early fourteenth century, there existed a port to which much pottery from various English sources was imported. In early modern times at Magor Pill, a vigorous outward trade in store cattle to west and south-west England was balanced by pottery imports chiefly from Devon and Somerset. Coastal erosion not only destroyed the primary evidence for these activities, and the wetland landscapes in which they occurred, but also forced, probably in late medieval times, the repositioning inland of the (?) Romano-British sea defences of the area. As part of the general process of reorganizing the defences and drainage of the wetland, the seabanks along Magor Pill and its tributaries were shortened in a number of stages and the outfalls moved further seaward. 


\section{NOTES}

I. Houghton et al. I990; Fulford et al. 1997. Global warming is likely to accelerate the rise of mean sea level, with attendant effects on tidal regime (ranges in Britain are generally increasing), and in mid latitudes could increase storminess. All of these effects may be expected either to initiate or augment coastal erosion, threatening archaeological resources, as well as sea defences, in the coastal zone.

2. Brooks I990.

3. Van de Noort and Davies I993; Van de Noort and Ellis, I995.

4. Hall and Coles I994.

5. Wilkinson and Murphy 1995.

6. Eddison and Green I988; Eddison 1995.

7. E.g. Bell I990; Allen and Fulford I987, 1990; Fulford et al. 1992, 1994; Rippon I996, I997.

8. Cunliffe I979.

9. Heighway 1983.

Io. Watts and Rahtz I985.

I I. Shoesmith I99I.

I2. We used a Coulter LS I30 laser grain-size analyser, dispersing while moist a subsample of the thoroughly mixed silt, without desalination or treatment with hydrogen peroxide, into a solution of $3.3 \%$ sodium hexametaphosphate and $0.7 \%$ sodium carbonate. This is an optimum procedure which affords highly reproducible results. The output we selected from the instrument takes the form of an histogram (differential grainsize distribution) in which the range of grain sizes from $0 . \mathrm{I} \mu \mathrm{m}$ to $900 \mu \mathrm{m}$ ( $\mathrm{I} 000 \mu \mathrm{m}=\mathrm{Imm})$ is divided into one hundred equal logarithmic classes. A range of calculated statistics form part of the output, including the mean and modal particle diameters, which we use below.

I3. Allen I990a.

I4. Allen and Rae 1987.

I5. Allen 1984, I987a.

16. Allen and Fulford 1986, I987; Allen I991, I993; Fulford et al. I994; Rippon I997, 97-IO3.

I7. Pethick 1992.

I8. Waller I994, 45.

I9. Welch and Trotter I96I.

20. Boon 1967; Locke 1970-I.

21. Andrews et al. 1984 .

22. Locke 1970-7I. Probable last-interglacial beach deposits capped by Devensian head are known from a number of boreholes and archaeological sondages along the north-western margin of the Gwent Levels. The most impressive and directly accessible evidence, however, is from the bedrock 'island' of Goldcliff, where Allen (in preparation) finds exposed a skirt of cemented, shelly beach sands and gravels overlain by head, with bovid bones and teeth, displaying involutions and possible ice-wedge casts.

23. The most probable calibrated ages (Stuiver and Becker 1993) for this set are: Cal. BC 4556-4454 (Beta-73058); Cal. BC 572-455 (Beta-73059).

24. Smith and Morgan I 989.

25. Allen and Rae 1987.

26. Allen $1987 \mathrm{~b}$

27. Allen and Rae 1987.

28. Ibid.

29. Shennan I989; Lambeck 1995.

30. Woodworth et al. I991. Relative mean sea level is rising at about $2.5 \mathrm{~mm} /$ year and the mean tidal range (Avonmouth) is expanding at about $\mathrm{Imm} /$ year.

31. Secular alterations in the wind-wave climate provide a regional process of medium-term coastal change; locally, the position of the coast can be influenced on the short to medium term by the migration of tidal channels and banks.

32. Allen and Pye 1992.

33. Allen I994; Woolnough et al. 1995.

34. Allen I 985.

35. Semifluid mud can be observed flowing in these features after most of the higher tides.

36. Little is known of archaeological formation processes in the coastal zone, and our list which follows must be regarded as provisional and incomplete. The topic continues to be a research challenge.

37. Hawkins (1973) disposed of a claimed 'Roman transgression' of the Somerset Levels by pointing out that occupation debris can be lodged in the bottoms of deep creeks well below marsh level, as well as on occupation surfaces at the altitude of the marsh platform.

38. As illustrated in the figure, the grain-size distribution curves of the silts from the palaeochannels can be seen to have a number of distinctive geometrical features. 
These are (a) modal points, at which the curves slopes down on each side, (b) shoulders or turning points, at which the curve more or less abruptly changes in slope, and (c) inflection points, at which there is a change in the sense of curvature. Differences in the number, grain-size and strength of these points lead to a simple classification of curve types. The classes are few, distinctive and, for the most part, distinct. However, because the silt while held in the water-column prior to deposition is in the form of loosely structured floccules and faecal aggregates, but the sample is analysed while dispersed into individual particles (see n. I2), a full sedimentological interpretation of these patterns is for the moment a matter of some uncertainty. This difficulty does not prevent the patterns from being reliably used for internal comparison and environmental characterization. It is at present surmized that the modes and turning points represent mineralogically distinct sub-populations of particles which contribute to the bulk sediment (e.g. quartz silt-sand and various clay-mineral species, all of which are known to be present). The coarser modes and turning points are already known to be linked to the presence of tidally-controlled laminae of quartz silt-sand in the deposits.

39. Whittle et al. I989.

40. An average rate of sea-level rise over the Iron Age of about $6 \mathrm{~mm} /$ year is implied.

4I. The calibrated dates (see n. 23) for wood and a stake-setting from this phase of the palaeochannel are: Cal. AD 4I8-544 (Beta-7I 596); Cal. AD 664-782 (Beta7I598); Cal. AD 689-888 (Beta-7I 595); Cal. AD 993-I035 (Beta-7I 597); Cal. AD 960-1005 (Beta-92999).

42. Allen I982, 24-5. The vigorous transport of sand and gravel along the bottom of a channel quickly sculptures a bed of stiff clay or rock into smoothly rounded, longitudinal furrows and ridges, accompanied by potholes and flute-like forms. Examples can be found during the European summer on the beds of many mountain streams.

43. The calibrated ages (see n. 23) for this set are: Cal. AD I669-I783, I797-I 949 (Beta-7I594); Cal. AD I650-80, I742-50 (Beta-7200I).

44. See n. 43.
45. Mellor et al. I994, I I I-40.

46. Nayling 1996.

47. Similar deposits are known from several other localities in the Severn Estuary (e.g. Allen and Fulford 1996), and express another, poorly understood formation process in the coastal zone. Possibly, the entrapment of artefacts arises because the gravel presents a rough surface over which it is difficult for sherds and bones to slide or roll.

48. Abattoir waste occasionally finds its way onto the shores of the Severn Estuary, but almost invariably the bones are little discoloured and carry saw marks.

49. Rippon 1997, fig. 6.

50. Allen and Rippon, I996.

51. Allen I990b; Allen and Fulford 1992, I996.

52. Allen and Fulford 1986; Allen 1993.

53. Astill I988; Hall I992, I995.

54. Rippon 1996.

55. RAF I946 CPE/UK I885 3055, 3056.

56. Astill I988; Hall I982, I995.

57. Hall i995.

58. National Library of Wales Map, Lockwood Vol. I, fol. I2. This map refers to a small estate to the north-east of Magor Pill and Pratt Reen, but the ground to the south-west is not shown.

59. Newport Reference Library M430/912.

60. Gwent Record Office Di365.I is a set of maps prepared for the Commissioners of Sewers. M430/9I2 is a small scale map of I756 showing the coast, including the position of the seabank, between Caldicot and the mouth of the Usk. To judge from other maps, the position of the seabank is somewhat generalized.

6I. Gwent Record Office Di365.I.

62. RAF I 946 CPE/UK I 8853065.

63. In the affected fields, ramps associated with a seaward rise in ground elevation (Allen I993) show where the seabank had been positioned.

64. Few quantitative data are available but, in the present wind-wave climate, the peat ledge seems to be retreating at about $0.25 \mathrm{~m} /$ year, in contrast to a retreat rate of about Im/year for the marsh cliff. Only the peat cliff is retreating on those parts of the Gwent coast where the marsh cliff has been protected by engineered work.

65. Whittle et al. I989.

66. Godbold and Turner 1994.

67. See n. 40. 
68. Most temperate-zone salt marshes afford examples of through-flowing channels which link two or more systems of otherwise dendritic, blind-ended creeks. Capture following headward erosion is one of the ways in which systems become joined.

69. National Library of Wales Map, Lockwood Vol. I, fol. I2; Newport Reference Library M430/912; Gwent Record Office Di365. I. See also n. 58, 60. 70. Barnett I96I; Boon I967.

7I. Locke (I970-7I, I3) infers that NashWilliams's pottery finds (I95I) were from a primary context. Although they came from the upper foreshore, it is much more likely, on both altitudinal (some metres below the level of the land-claim) and stratigraphical grounds (only the Rumney and Awre Formations existed at the time south-west of Magor Pill), that the sherds had become stratified after transposition, into the base of the Awre Formation where it erosively overlay green Wentlooge silts.

72. Boon I980.

73. Knight 1962.

74. The crude inscription on the stone is interpreted by Knight to state that 33.5 paces of an earthwork structure had been built by a century from the first cohort of Legio II Augusta, under the command of one Statorius Maximus. Because the stone was found (1878) on the shore outside the bounds of the modern seabank, Knight concluded that it cast doubt on a possible Roman embankment of the Caldicot Level. He was, however, unaware of the evidence that the modern defence was in a set-back position (post-Roman), and that it was possibly from the Rumney Formation (some survives today near the find spot), into the base of which the stone may have been transposed, that the stone was released during later coastal retreat. Statorius Maximus and his century could well have been working on a seabank along Magor Pill at a position well inland from the line of the contemporaneous defence along the open coast.

75. Allen and Rae I988; Allen I991. These authors find an elevation difference across a seabank of c. I.5m with some local variation as typical of Romano-British land-claims in the Severn Estuary. A significantly smaller difference, assuming a Roman date for the primary claim, implies post-Roman neglect of the defences and flooding prior to resettlement and the making good of the surviving banks and ditches. A buried field system, or at least a buried soil, should be detectable in the case of such a man-inspired 'transgression' (Allen I993).

76. Bell I995.

77. Williams I965.

78. Allen ig9oa.

79. Allen and Fulford I986; Allen I990b; Fulford et al. I994.

80. Allen and Fulford 1992, I 996.

81. Gwent Record Office Di365. I See n. 60.

82. At some time in the last decade, a tortuous loop in the channel of Goldcliff Pill where it crosses the upper foreshore has been straightened by a cut across the neck, in order to protect the foot of the seabank to the south-west of the channel. If $\mathrm{M}_{43}$ / $9 \mathrm{I} 2$ (see n. 60) is to be totally relied upon, the rerouting of Magor Pill occurred between 1756 and I830, and involved a slight, local set-back of the defence (not shown in fig. 22).

83. Bell i993.

84. Nash-Williams I95I.

85. Bell i995.

86. Fulford et al. 1994 .

87. Allen and Fulford I996. Crandon Bridge on the River Parrett in Somerset, linked to Ilchester by road along the Polden Hills, is the more likely port serving the Bristol Channel and Severn Estuary than the better known but chronologically earlier and less directly connected Sea Mills on the Avon.

88. Rippon I997, 65-74.

89. Cal. Charter Rolls iii, 88-97.

90. Cal. Inq. Post Mortem I Edw. III, No. 46.

9I. Bradney I929.

92. Robinson 1972.

93. Williams I965.

94. Silby 1927.

95. Silby I927; Gayer and Criddle I970; Rankin and Criddle I985; Waters and Lawrence 1987; Wilson et al. 1990

96. Cantrill et al. I9I9; Gough I930; Green and Welch I965; Alabaster I982; Kellaway and Welch I 993.

97. Matthews 1900; Skeel 1926; Lewis 1927; Betty 1983.

98. Gwent Record Office D25/228. This is a deed referring to a house on 'the way 
leading from the crosse at Magor toward Aberwaythan Pill'.

99. National Library of Wales Map, Lockwood Vol I, fol. I2; Newport Reference Library M430/912. See n. 58, 60.

Ioo. Cf. Wood i9i4.

IOI. Newport Reference Library M430/912. See n. 60

I02. Grove 1988.

I03. Courtney I986-7.

I04. The lower part of the Lower Old Red Sandstone of Gwent is formed of red, micaceous, silty mudrocks, accompanied by subordinate, coarsely micaceous sandstones.

I05. Courtney I986-7.

I06. Matthews I900; Skeel I926; Bettey I983.

I07. McDonnell I980; Green 1992; Godbold and Turner 1994.

I08. Godbold and Turner 1994, pl. VC.

I09. Green 1992.

I IO. Green I992; Salisbury I99I, fig II.8; Godbold and Turner 1994, pl. VA, $B$.

I I I. Godbold and Turner I994, context 238.

I I2. Salisbury I99I.

II3. Godbold and Turner I994, contexts 230, $26 \mathrm{I}$.

I I4. Allen forthcoming.
I I5. Parry and McGrail I99I.

I I6. Lawler and Nayling I993.

I I 7. This site, much nearer the outer margin of the Caldicot Level than the modern coast, has yielded a c. Iom Roman boat preserved in a silted-up tidal channel. The boat can only have been brought to the site through a network of even larger creeks, no traces of which now survive as ground features.

I I8. Rippon I997, 65-74; forthcoming

I I9. Allen and Fulford I996.

I20. Scarth I 886 .

I2 I. Rippon I977, 8I-9I.

I22. Allen and Fulford 1987, I992; Allen and Rippon forthcoming.

I23. Allen and Fulford 1996.

I24. Fulford et al. I992.

I25. Davies and Williams I99I.

I26. Wright and Churchill 1985.

I27. Nationally, extremely few redundant seabanks or outfall works have so far been entered in Sites and Monuments Records, and practically none have protected status.

I28. Shortenings of respectively $c$. I $4 \mathrm{~km}$ and c. $16 \mathrm{~km}$ were achieved in the Essex (Grieve 1959, 843) and Kent (Summers I978, I27) coastal marshlands.

\section{BIBLIOGRAPHY}

Alabaster, C.J. I982. 'The minerals of Mendip', 7. Somerset Mines Res. Group, I(4), I-52

Allen, J.R.L. I982. Sedimentary Structures, their Character and Physical Basis, vol. 2, Amsterdam

Allen, J.R.L. I984. 'Truncated fossil thermal contraction polygons (?Devensian) in the Mercia Mudstone Formation (Trias), Oldbury upon Severn, Gloucestershire', Proc. Geol. Ass., 95, 262-73

Allen, J.R.L. I985. 'Intertidal drainage and mass-movement processes in the Severn Estuary: rills and creeks (pills)', F. Geol. Soc. London, I42, 849-6I

Allen, J.R.L. I987a. 'Dimlington Stadial (late Devensian) ice-wedge casts and involutions in the Severn Estuary, south-west Britain', Geol. F., 22, 109-I8

Allen, J.R.L. I987b. 'Late Flandrian shoreline oscillations in the Severn Estuary: the Rumney Formation at its typesite (Cardiff area)', Phil. Trans. Roy. Soc. London, B3 5 , I $57-84$
Allen, J.R.L. I990a. 'The Severn Estuary in south-west Britain: its retreat under marine transgression, and fine-sediment regime', Sedimentary Geol., 66, I3-28

Allen, J.R.L. I990b. 'Reclamation and sea defence in Rumney Parish (Monmouthshire)'. Archaeol. Cambrensis, I37, I35-40

Allen, J.R.L. I991. 'Salt-marsh accretion and sea-level movement in the inner Severn Estuary: the archaeological and historical contribution', F. Geol. Soc. London, I48, 485-94

Allen, J.R.L. I993. 'Muddy alluvial coasts of Britain: field criteria for shoreline position and movement', Proc. Geol. Ass., I04, 24I62

Allen, J.R.L. I994. 'A continuity-based sedimentological model for temperatezone tidal salt marshes', f. Geol. Soc. London, I 5 I, 4I-9

Allen, J.R.L. forthcoming. 'Three latest Bronze Age occupations at Rumney Great 
Wharf on the Wentlooge Level, Gwent', Studia Celtica

Allen, J.R.L. and Fulford, M.G. I986. 'The Wentlooge Level: a Romano-British saltmarsh reclamation in southeast Wales', Britannia, I7, 9I-II 7

Allen, J.R.L. and Fulford, M.G. I987. 'Romano-British settlement and industry on the wetlands of the Severn Estuary', Antiq. F., 67, 237-89

Allen, J.R.L. and Fulford, M.G. I990 [1992]. 'Romano-British wetland reclamations at Longney, Gloucestershire, and the evidence for early settlement of the inner Severn Estuary', Antiq. F., 70, 288-326

Allen, J.R.L. and Fulford, M.G. I992. 'RomanoBritish and later geoarchaeology at Oldbury Flats: reclamation and settlement on the changeable coast of the Severn Estuary, south-west Britain', Archaeol. F., I49, 82-I23

Allen, J.R.L. and Fulford, M.G. I996. 'Late Flandrian coastal change and tidal palaeochannel development at Hills Flats, Severn Estuary (SW Britain)', f. Geol. Soc. London, I 53, I 5 I-62

Allen, J.R.L. and Fulford, M.G. I996. 'The distribution of South-east Dorset Black Burnished Category I pottery in southwest Britain', Britannia, 27, 223-8I

Allen, J.R.L. and Pye, K. (eds.) 1992. Saltmarshes, Morphodynamics, Conservation and Engineering Significance, Cambridge

Allen, J.R.L. and Rae, J.E. I987. 'Late Flandrian shoreline oscillations in the Severn Estuary: a geomorphological and stratigraphical reconnaissance', Phil. Trans. Roy. Soc. London, B315, I85-230

Allen, J.R.L. and Rae, J.E. I988. 'Vertical saltmarsh accretion since the Roman period in the Severn Estuary, south-west Britain', Marine Geol., 83, 225-35

Allen, J.R.L. and Rippon, S.J. I996. 'The historical simplification of coastal flood defences: four case histories from the Severn Estuary Levels', Trans. Bristol Gloucestershire Archaeol. Soc., I I3, 73-88

Allen, J.R.L. and Rippon, S.J. forthcoming. 'A Romano-British shaft of dressed stone and the settlement at Oldbury on Severn, County of Avon', Trans. Bristol Gloucestershire Archaeol. Soc.

Andrews, J.T., Gilbertson, D.D. and Hawkins, A.B. I984. 'The Pleistocene succession of the Severn Estuary: a revised model based upon amino acid recemization studies', $\mathcal{F}$. Geol. Soc. London, I4I, 967-74
Astill, G. I988. 'Fields' in The Countryside of Medieval England (eds. G. Astill and A. Grant), Oxford, 62-85

Barnett, C. I96I. 'A find of Roman pottery at Uskmouth', Monmouthshire Antiq., I(I), I2-I3

Bell, M. I990. Brean Down Excavations 198387, English Heritage Archaeol. Rep., I5, London

Bell, M. I993. 'Field survey and excavation at Goldcliff, Gwent I993' in Archaeology in the Severn Estuary I993 (ed. M. Bell), Annu. Rep. Severn Estuary Levels Res. Comm., Lampeter, 8I-IOI, I I9-25

Bell, M. I995. 'Field survey and excavation at Goldcliff, Gwent 1994' in Archaeology in the Severn Estuary 1994 (ed. M. Bell), Ann. Rep. Severn Estuary Levels Res. Comm., Lampeter, I I 5-44, I 57-65

Bettey, J.H. I983. 'Livestock trade in the West Country during the seventeenth century', Proc. Somerset Archaeol. Natur. Hist. Soc., I 27, I23-28

Boon, G.C. I967. 'Roman pottery from the base of the alluvium at Magor', Monmouthshire Antiq., 2(3), I2 I-27

Boon, G.C. I980. 'Caerleon and the Gwent Levels in early historic times' in Archaeology and Coastal Change (ed. F.H. Thompson), Soc. Antiq. London Occ. Pap. (new ser.), I, 24-36, London

Bradney, J. 1929. A History of Monmouthshire, Part I of Vol. IV. The Hundred of Caldicot, London

Brooks, I.P. I990. The Lindsey Coastal Survey 1989-90, Lincoln Archaeol. Services, Lincoln

Cantrill, T.C., Sherlock, R. and Dewey, H. 1919. Special Reports on the Mineral Resources of Great Britain. IX - Iron ores: Sundry Unbedded Ores of Durham, east Cumberland, North Wales, Derbyshire, the Isle of Man, Bristol District and Somerset, Devon and Cornwall, Memoirs Geol. Survey Great Britain, London

Courtney, P. I986-87. 'Some exotic 'imports' and other wares from the South Wales coast', Medieval Later Pottery Wales, 9, 23-30

Cunliffe, B. (ed.) 1979. Excavations in Bath, 1950-I975, Comm. Rescue Archaeol. Avon, Gloucestershire and Somerset Excavation Rep., I, Bristol

Davies, P. and Williams, A.T. I99I. 'The enigma of the destruction of Colhuw port, Wales', Geogr. Rev., 8I, 257-66 
Eddison, J. I995. Romney Marsh: the Debatable Ground, Oxford Univ. Comm. Archaeol. Monogr., 4I, Oxford

Eddison, J. and Green, R.D. I988. Romney Marsh: Evolution, Occupation, Reclamation, Oxford Univ. Comm. Archaeol. Monogr., 24, Oxford

Fulford, M.G., Allen, J.R.L. and Rippon, S.J. I994. 'The settlement and drainage of the Wentlooge Level, Gwent: excavation and survey at Romney Great Wharf 1992', Britannia, 25, I75-2I I

Fulford, M.G., Champion, T.C. and Long, A.J. I997. England's Coastal Heritage, London

Fulford, M.G., Rippon, S.J., Allen, J.R.L. and Hillam, J. 1992. 'The medieval quay at Woolaston Grange, Gloucestershire', Trans. Bristol Gloucestershire Archaeol. Soc., I IO, IOI-I 27

Gayer, R.A. and Criddle, A.J. I970. 'Mineralogy and genesis of the Llanharry iron ore deposits, Glamorgan' in Mining and Petroleum, London, 605-26

Godbold, S. and Turner, R.C. I 994. 'Medieval fishtraps in the Severn Estuary', Medieval Archaeol., 38, I9-54

Gough, J.W. I930. The Mines of Mendip, Oxford

Green, C. I992. 'The Severn fisheries' in Archaeology in the Severn Estuary 1992 (ed. M. Bell), Annu. Rep. Severn Estuary Levels Res. Comm., Lampeter, 69-76

Green, G.W. and Welch, F.B.A. 1965. Geology of the Country around Wells and Cheddar, Memoirs Geol. Survey Great Britain, London

Grieve, H.E.P. 1959. The Great Tide, Chelmsford

Grove, J.M. I988. The Little Ice Age, London

Hall, D. I982. Medieval Fields, Princes Risborough

Hall, D. I995. The Open Fields of Northamptonshire, Northampton

Hall, D. and Coles, J. I994. Fenland Survey. An Essay in Landscape and Persistence, English Heritage Archaeol. Rep., I, London

Hawkins, A.B. I973. 'Sea-level changes around south-west England' in Marine Archaeology (ed. D.J. Blackman), London, 67-87

Heighway, C. 1983. The East and North Gates of Gloucester and Associated Sites: Excavations I974-8I, Western Archaeol. Trust Excavation Monogr., 4, Bristol

Houghton, J.T., Jenkins, G.J. and Ephraims, J.J. I990. Climate Change. IPCC Scientific Assessment, Cambridge
Kellaway, G. and Welch, F.B.A. I993. Geology of the Bristol District, Memoirs Geol. Survey Great Britain, London

Knight, J.K. I962. 'The Goldcliff stone - a reconsideration', Monmouthshire Antiq., I(2), 34-6

Lambeck, K. I995. 'Late Devensian and Holocene shorelines of the British Isles and North Sea from models for glaciohydro- isostatic rebound', F. Geol. Soc. London, I 52, 437-48

Lawler, M. and Nayling, N. 1993. 'Investigations at Barland's Farm, Magor, I993' in Archaeology in the Severn Estuary I993 (ed. M. Bell), Annu. Rep. Severn Estuary Levels Res. Comm., Lampeter, I09-I2, I I9-25

Lewis, E.A. 1927. The Welsh Port Books (I550-I603), Cymmrodorion Rec. Ser., I2, London

Locke, S. I970-7I. 'The post glacial deposits of the Caldicot Level and the associated archaeological discoveries', Monmouthshire Antiq, 3(I), I-I6

Matthews, J.H. I900. Cardiff Records, being Material for a History of the County Borough from the Earliest Times, Cardiff

McDonnell, R.R.J. I980. 'Tidal fishweirs, West Somerset', Proc. Somerset Archaeol. Natur. Hist. Soc., I23, 75-82

Mellor, M., Cowell, M., Newns, S. and Vince, A. I994. 'A synthesis of middle and late Saxon, medieval and early post-medieval pottery in the Oxford region', Oxoniensia, 59, I 7-2I 7

Nash-Williams, V.E. I95I. 'New Roman site at Redwick (Mon.)'. Bull. Board Celtic Stud., I 4, 254-55

Nayling, N. I996. 'The excavation, recovery and provisional analysis of a medieval wreck from Magor Pill, Gwent Levels' in Archaeology in the Severn Estuary 1995 (ed. M. Bell), Annu. Rep. Severn Estuary Levels Res. Comm., vol 6, 85-95, I I2-22, Lampeter

Parry, S.J. and McGrail, S. I99I. 'A prehistoric plank boat fragment from Caldicot Castle Lake, Gwent', Int. $\mathcal{F}$. Naut. Archaeol., 20, 32 I-4

Pethick, J.S. I992. 'Saltmarsh geomorphology' in J.R.L. Allen and K. Pye (eds.), Cambridge, $4 \mathrm{I}-62$

Rankin, A.H. and Criddle, A.J. I985. 'Mineralising fluids and metastable low temperature inclusion brines at Llanharry 
iron deposits, South Wales'. Trans. Inst. Mining Metallurgy, 94, Bı26-B⿵ 32

Rippon, S.J. 1996. The Gwent Levels: the Evolution of a Wetland Landscape, Council Brit. Archaeol. Res. Rep., I05, London

Rippon, S.J. 1997. The Severn Estuary: Landscape Evolution and Wetland Reclamation, Leicester

Rippon, S.J. forthcoming. 'Roman settlement and salt production on the Somerset coast: the work of Samuel Nash, a Somerset archaeologist and historian 1913-1985', Proc. Somerset Archaeol. Natur. Hist. Soc., I39

Robinson, W.R.B. I972. 'Dr Thomas Phaer's report on the harbours and customs administration of Wales under Edward VI', Bull. Board Celtic Stud., 24, 485-503

Salisbury, C.R. I99I. 'Primitive British fishweirs' in Waterfront Archaeology (eds. G.L. Good, R.H. Jones and M.W. Ponsford), Council Brit. Archaeol. Res. Rep., 74, 76-87, London

Scarth, H.M. I886. 'The Roman villa Wemberham in Yatton: and discovery of Roman coins near Kingston Seymour', Proc. Somerset Archaeol. Natur. Hist. Soc., $3 \mathrm{I}(2), \mathrm{I}-9$

Shennan, I. 1989. 'Holocene crustal movements and sea-level changes in Great Britain', f. Quaternary Science, 4, 77-89

Shoesmith, R. I991. Excavations at Chepstow 1973-I974, Cambrian Archaeol. Ass. Monogr., 4, Bangor

Sibly, T.F. 1927. Special Reports on the Mineral Resources of Great Britain. X Iron Ores - the Haematites of the Forest of Dean and South Wales, Memoirs Geol. Survey Great Britain, London

Skeel, C. I926. 'The cattle trade between Wales and England from the fifteenth to nineteenth centuries', Trans. Roy. Hist. Soc., (4)9, I35-58

Smith, A.G. and Morgan, L.A. I989. 'A succession to ombrotrophic bog in the Gwent Levels, and its demise: a Welsh parallel to the peats of the Somerset Levels', New Phytologist, I I2, I 45-67

Stuiver, M. and Becker, B. I993. 'Highprecision decadal calibration of the radiocarbon time scale, AD I950-BC 6000', Radiocarbon, 35, 35-66

Summers, D. I978. The East Coast Floods, Newton Abbot

Van de Noort, R. and Davies, P. I993. Wetland Heritage. An Archaeological Assessment of the Humber Wetlands (ed. S. Ellis), Kingston upon Hull

Van de Noort, R. and Ellis, S. 1995. Wetland Heritage of Holderness. An Archaeological Survey, Humber Wetlands Project, Univ. Hull

Waller, M. 1994. The Fenland Project, Number 9: Flandrian Environmental Change in the Fenland, East Anglian Archaeol. Rep., 70, Cambridge

Waters, R.A. and Lawrence, D.J.D. 1987. Geology of the South Wales Coalfield. III. The Country around Cardiff, Memoirs Geol. Survey Great Britain, London

Watts, L. and Rahtz, P. I985. Mary-le-port, Bristol. Excavations 1962-63, City of Bristol Museum and Art Gallery Monogr., 7, Bristol

Welch, F.B.A. and Trotter, F.M. 1961. The Country around Monmouth and Chepstow, Memoirs Geol. Survey Great Britain, London

Whittle, A.W.R., with Antoine, S., Gardiner, N., Milles, A. and Webster, P. I989. 'Two later Bronze Age occupations and an Iron age channel on the Gwent foreshore', Bull. Board Celtic Stud., 36, 200-23

Wilkinson, T.J. and Murphy, P. 1995. The Archaeology of the Essex Coast, Vol. I: The Hullbridge Survey, East Anglian Archaeol. Rep., 7 I, Cambridge

Williams, D. 1965. 'Tintern Abbey: its economic history', Monmouthshire Antiq., 2(I), I-32

Wilson, D., Davies, J.R., Fletcher, C.H.J.N and Smith, M. 1990. Geology of the South Wales Coalfield. VI. The Country around Bridgend, Memoirs Geol. Survey Great Britain, London

Wood, J.G. I9I4. The Manor and Mansion of Moynes Court, Monmouthshire (with an Appendix on the Ancient Harbours of South Monmouthshire), Newport

Woodworth, P.L., Shaw, M.S.M. and Blackman, D.L. I991. 'Secular trends in mean tidal range around the British Isles and along the adjacent European coastline', Geophysical F. Int., I04, 593-609

Woolnough, S.J., Allen, J.R.L. and Wood, W.L. I995. 'An exploratory numerical model of sediment deposition over tidal salt marshes', Estuarine Coastal and Shelf Science, 4I, 5I 5-43

Wright, E.V. and Churchill, D.M. I965. 'The boats of North Ferriby, Yorkshire, England', Proc. Prehist. Soc., 3 I, I-24 